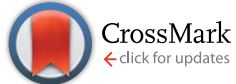

Cite this: RSC Adv., 2016, 6, 104763

Received 26th September 2016

Accepted 24th October 2016

DOI: $10.1039 / c 6 r a 23940 d$

www.rsc.org/advances

\section{Quinoline based mono- and bis-(thio) carbohydrazones: synthesis, anticancer activity in 2D and 3D cancer and cancer stem cell models $\dagger$}

\author{
Aleksandra Božić, ${ }^{a}$ Aleksandar Marinković, ${ }^{a}$ Snežana Bjelogrlić, ${ }^{b}$ \\ Tamara R. Todorović, ${ }^{c}$ Ilija N. Cvijetić, ${ }^{d}$ Irena Novaković, ${ }^{\text {e }}$ Christian D. Muller ${ }^{f}$ \\ and Nenad R. Filipović ${ }^{\star g}$
}

A comparative study of antitumor activity of mono- and bis-quinoline based (thio)carbohydrazones was investigated by a series of tests on two human malignant cell lines: acute monocytic leukemia (THP-1) and pancreatic adenocarcinoma cancer stem cells (AsPC-1). Thiocarbohydrazones (TCHs) revealed superior pro-apoptotic activity over carbohydrazones $(\mathrm{CHs})$ on both tested cell phenotypes, also displaying multi-target profile activities. Programmed cell death triggered by TCHs was partially caspasedependent, mainly caspase- 8 related. Activity against cancer stem cells (CSCs) was evaluated on 2D monolayers and 3D spheroidal models, where two out of three tested bis-TCHs successfully stimulated apoptosis accompanied by a reduction in size of treated spheres. Additionally, all bis-TCHs induced significant decrease in percentage of CD44-expressing AsPC-1 cells that indicate on their ability to induce reprogramming of CSC phenotype. Current results highly support further assessment of bisTCHs in order to specify their specific targets in cancer cells and particularly in the CSCs subpopulation.

\section{Introduction}

Hydrazones are condensation products of hydrazine or its alkyl, acyl and aryl analogues with carbonyl compounds. They are known to possess a broad spectrum of biological activities such as antioxidant, analgesic, antiplatelet, antimicrobial, anticonvulsant, antidepressant, anti-inflammatory, anti-tubercular, cardio protective, anti-HIV, anthelmintic, anti-diabetic, trypanocidal and anticancer activities..$^{1-6}$ Many of these compounds were patented in this respect. ${ }^{7}$ Monohydrazide derivatives of carbonic and thiocarbonic acid, semicarbazide and thiosemicarbazide, respectively react with N-heteroaromatic carbonyl compounds giving (thio)semicarbazones - molecules well described as tridentate $\mathrm{NNO}(\mathrm{S})$ chelators and ribonucleotid

${ }^{a}$ Faculty of Technology and Metallurgy, University of Belgrade, Karnegijeva 4, Belgrade, Serbia

${ }^{b}$ National Cancer Research Center of Serbia, Pasterova 14, Belgrade, Serbia ${ }^{c}$ Faculty of Chemistry, University of Belgrade, Studentski trg 12-16, Belgrade, Serbia ${ }^{d}$ Innovation Center of the Faculty of Chemistry, University of Belgrade, Studentski trg 12-16, Belgrade, Serbia

${ }^{e}$ Institute of Chemistry, Technology and Metallurgy, University of Belgrade, Njegoševa 12, Belgrade, Serbia

${ }^{f}$ Institut Pluridisciplinaire Hubert Curien, UMR 7178, CNRS, Université de Strasbourg, 67401 Illkirch, France. E-mail: cdmuller@unistra.fr

${ }^{g}$ Faculty of Agriculture, University of Belgrade, Nemanjina 6, Belgrade, Serbia. E-mail: nenadf.chem@gmail.com

$\dagger$ Electronic supplementary information (ESI) available. See DOI: 10.1039/c6ra23940d reductase (RR) inhibitory agents. ${ }^{8}$ RR plays a fundamental role in the critical early events involved in tumor promotion and activity of this enzyme is tightly linked to the neoplastic expression state and is currently one of the main targets for DNA inhibition by anticancer agents. ${ }^{9}$

The most studied hydrazone is triapine (3-amino-2formylpyridine thiosemicarbazone) since more than 30 clinical phase I and phase II trials has been done so far. ${ }^{\mathbf{1 0}}$ Triapine was developed in 1994 as an RR inhibitor and its mechanism of action was thought to be iron chelation from RR active site. ${ }^{\mathbf{1 1}}$ Later on its iron(II) complex was supposed to be active species which inhibits RR indirectly by generation of reactive oxygen species (ROS) which are formed in Fentone type reactions. ${ }^{\mathbf{1 2}}$ Recent evidences proved that iron(II) complex inhibits RR, but probably via direct tyrosil radical quenching not involving ROS. ${ }^{13}$ There are also different theories were and how the active $\mathrm{Fe}(\mathrm{II})$-triapine complex is formed in the body. For example, one study resulted in the model which proposed triapine binding for RR surface, followed by labilization of the diferric center and iron complex formation. ${ }^{\mathbf{1 4}}$ On the other hand, there are evidences that interaction of triapine with iron occurs in the liver, which is known as the site of ferritin production. ${ }^{15}$ Unrevealing of triapine's mechanism of activity is still the topic of interest. Recently mitochondria ${ }^{\mathbf{1 6 , 1 7}}$ and endoplasmatic reticulum $^{18}$ were recognized as new triapine biological targets.

Carbohydrazide and thiocarbohydrazide are dihydrazide derivatives of carbonic and thiocarbonic acids. As their monohydrazide analogues (thio)semicarbazide, (thio)carbohydrazide 
also form corresponding monohydrazones. The presence of additional hydrazide group allows preparation of dihydrazones. Despite the fact that mono- and bis-(thio)carbohydrazides are also known to chelate iron, ${ }^{19-25}$ which make them potential RR inhibitors, there are only few investigations published where their anticancer activities were explored, ${ }^{25-33}$ with no study about their possible mechanism of action.

Quinoline is a privileged scaffold in anticancer drug discovery $^{34}$ and various quinoline (thio)semicarbazones showed promising results when tested against cancer cell lines. ${ }^{35-40}$ Here, we present results of the first systematically organized investigation of antitumor activity of three mono-carbohydrazones and three mono-thiocarbohydrazones with their corresponding bisstructural counterparts. Despite the development of new therapeutics with increasing success in treating malignancies, recurrence of disease can develop years after efficient therapy. It was demonstrated that a small fraction of cells residing at the top of genetic hierarchy within solid tumors, declared as cancer stem cells (CSCs), are responsible for disease relapse. ${ }^{41}$ CSCs are also assigned culpable for tumor growth, progression, dissemination and resistance to therapy. Specified important role of CSCs in tumor growth, metastases and relapse, define that the major goal in effort to cure the cancer should be elimination or terminal differentiation of CSCs. Currently, there is no available treatment option proved as efficient against this subpopulation of cancer cells. Apart from having significantly enhanced DNA repairing mechanisms, CSCs hold a unique strategy to avoid the harmful effects of chemotherapeutic and radiation treatments which exclusively affect proliferating cells. There are several circumstances when CSCs resort the dormancy phase to gain genetic and epigenetic alterations that are necessary for neoplastic conversion, adaptation to new microenvironment and survival. $^{\mathbf{4 2 , 4 3}}$ Therapy-induced dormancy describes response of CSCs to repeated cycles of therapy that enter a dormant phase and thereafter relapse as a more aggressive phenotype. ${ }^{44}$ To eliminate CSCs, applied treatments should induce their apoptotic death, or to interferes with their hideaway in dormancy phase by stimulating mitotic division thus increasing their vulnerability to chemo and radiotherapy. Therefore, in order to investigate ability of our compounds to act as comprehensive anti-cancer agents with competency to eliminate both CSCs and non-CSCs, current biological study was organized on two diverse cell lines acute monocytic leukemia (THP-1) and pancreatic adenocarcinoma cancer stem cells (AsPC-1), where AsPC-1 cells are highly expressing CSC phenotype. ${ }^{\mathbf{4 5 , 4 6}}$ Additionally, alongside standardly used 2D monolayer model, we here also used spheroidal 3D culture as more accurate screening platform for drug activity considering its architecture well mimics in vivo tumor mass.

\section{Results and discussion}

\section{Chemistry}

Carbohydrazones (CHs) O1-O6 and thiocarbohydrazones (TCHs) S1-S6 were prepared by the condensation reaction of carbonic acid dihydrazide (dhO) or its sulphur analogue thiocarbonic acid dihydrazide (dhS) and appropriate aldehyde (Scheme 1). The synthesis of $\mathbf{O 4}$ and $\mathbf{S 4}$ have been published
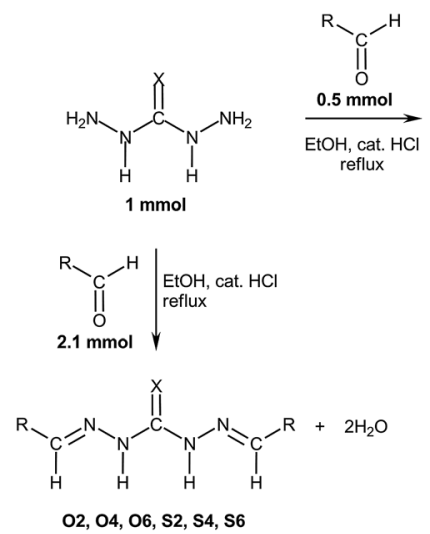

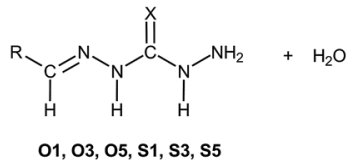

$\mathrm{X}=\mathrm{O}$

01, O2: $R=8$-quinolinyl

O3, O4: $R=2-q$ -

$X=S$

S1, S2: $R=8$-quinolinyl

S5, S6: $R=8$-hydroxy-2-quinolinyl
Scheme 1 General procedure for the synthesis of carbohydrazones O1-O6 and thiocarbohydrazones S1-S6.

earlier. ${ }^{47}$ The composition and purity of all compounds was verified by elemental analysis, while their structural characterization was done by IR and NMR spectroscopy.

In order to optimize geometries of the all compounds DFT calculations were performed. There are significant structural differences between optimized geometries of $\mathrm{CHs}$ and TCHs (Table 1). Analogue monohydrazones differ in the chalcogen atom orientation, while in the case of bis-hydrazones symmetrical conformations were obtained in the case of $\mathrm{CHs}$ and unsymmetrical ones in the case of TCHs. Optimized geometries of bis-hydrazones are in accordance with data obtained by NMR spectroscopy. Results of the GIAO/B3LYP calculations of the ${ }^{1} \mathrm{H}$ and ${ }^{13} \mathrm{C}$ chemical shifts of all compounds are shown in ESI (Tables S1-S5†). Namely, the main difference between ${ }^{1} \mathrm{H}$ NMR spectra of oxygen based bis-hydrazones (bis-CHs) and sulphur based bis-hydrazones (bis-TCHs) is presence of two distinct signals for both, hydrazide and imine nitrogen protons in the case of sulphur compounds. The presence of two distinct signals for $\mathrm{NH}$ protons was already reported for bis-TCHs, ${ }^{48}$ and that phenomenon was explained by the presence of intermolecular hydrogen bonds between hydrazide hydrogen atom and imine nitrogen atom, while in the case of bis-CHs there is no such hydrogen bond.

All compounds obey Lipinski's rule of five, ${ }^{49}$ (Table S6, ESI $\dagger$ ) so these compounds are drug-like, with promising bioavailability and pharmacokinetics. The proton donating ability of investigated quinoline based (thio)carbohydrazones 01-06 and S1-S6 was assayed using a protocol for the determination of radical scavenging activity, the DPPH (1,1-diphenyl-2picrylhydrazyl radical) method..$^{50}$ Ascorbic acid was used as the reference compound (positive control). To the best of our knowledge there is no systematic comparative study of freeradical scavenging activity of $\mathrm{CHs}$ and TCHs. Our results indicate that TCHs were far more active in DPPH radical scavenging than their oxygen counterparts, with $\mathrm{IC}_{50}$ values close to that of vitamin $\mathrm{C}$ (Table 1). In both group of compounds, those which contain hydroxyl group are the most active, in the case of both mono- and bis-hydrazones. It seems that the main reason for pronounced antioxidant activity of TCHs is presence of thione $(\mathrm{C}=\mathrm{S})$ group, since the obtained $\mathrm{IC}_{50}$ values are in the narrow 
Table 1 Optimized geometries of the compounds $\mathrm{O} 1-\mathrm{O} 6$ and $\mathrm{S} 1-\mathrm{S} 6$ and IC 50 values $(\mathrm{mM})$ determined by DPPH method

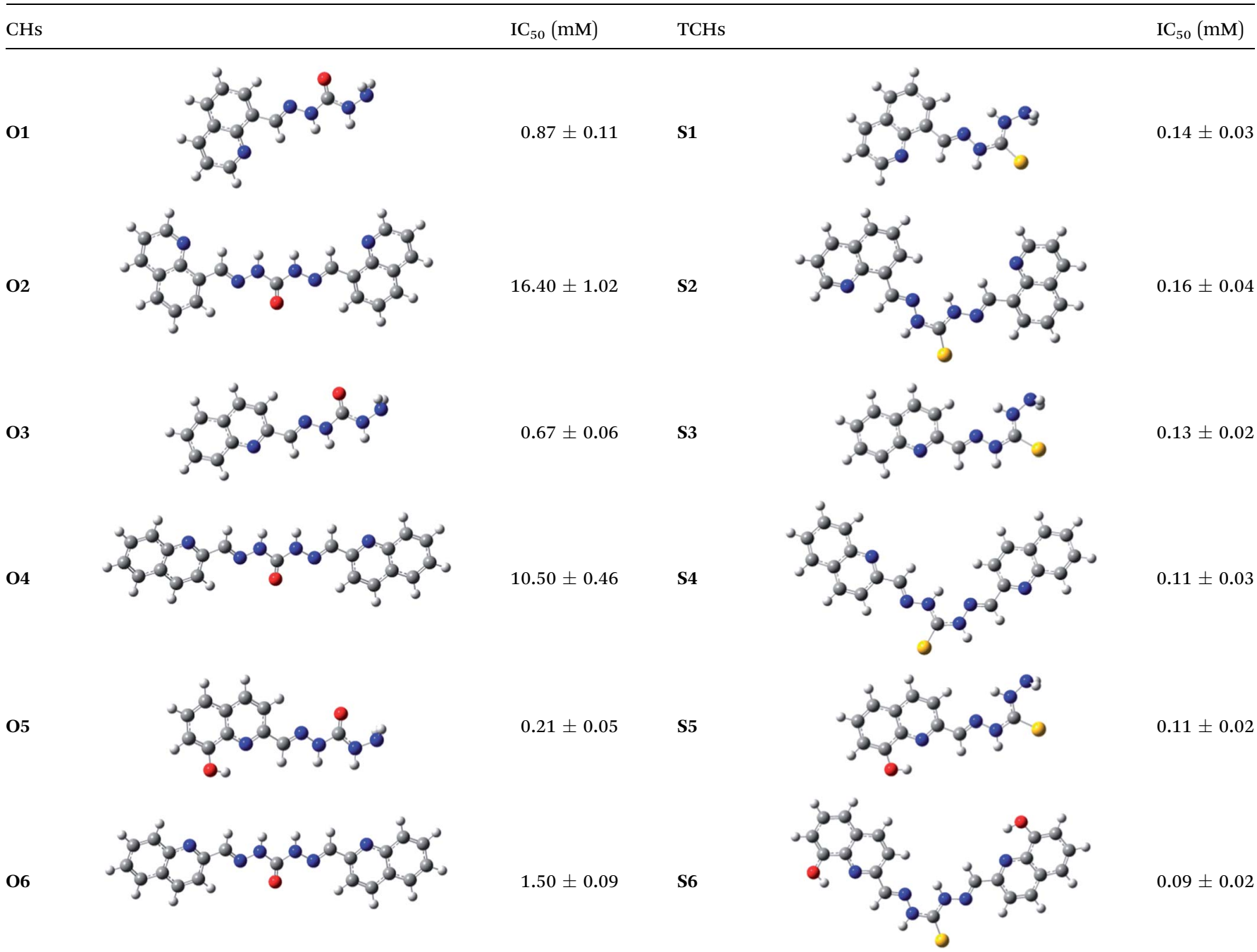

Ascorbic acid

$0.08 \pm 0.01$

range (0.09-0.16 $\mathrm{mM})$, while $\mathbf{S 6}$ had almost the same activity as vitamin C. Other thione antioxidants such as ergoteine and thiosemicarbazones are well known for their free-radical scavenging activities. ${ }^{\mathbf{5 1 , 5 2}}$ In the case of CHs, mono derivatives are 719 times more active than their bis-hydrazone analogues, which indicates a role of free $-\mathrm{NH}-\mathrm{NH}_{2}$ group in the mechanism of their antioxidant activity. More detailed study of antioxidant activities of CHs and TCHs, which has a goal to decipher the mechanism of action, is currently in progress in our group.

\section{Investigation of anticancer activities}

TCHs has substantially higher pro-apoptotic activity. Activity of investigated compounds was evaluated after $24 \mathrm{~h}$ incubation with the cells, initially applied in a range of six concentrations from 1-100 $\mu \mathrm{M}$. In regard to structure-activity relationship, all TCHs revealed pro-apoptotic activity on THP-1 cells, while compound $\mathbf{O} 2$ was the only $\mathrm{CH}$ with ability to induce death on this cell line (Table 2 and Fig. S1, ESI $\dagger$ ). Contrary to O2, 06 was another $\mathrm{CH}$ with activity against THP-1 cells, but yielded
Table 2 The $\mathrm{ED}_{50}$ concentrations $(\mu \mathrm{M})$ achieved after $24 \mathrm{~h}$ treatment of THP-1 and AsPC-1 cell lines with investigated $\mathrm{CHs}$ and $\mathrm{TCH}$. Results are expressed as the mean \pm SD of two replicates from independent experiments

\begin{tabular}{llllll}
\hline CHs & THP-1 & AsPC-1 & TCHs & THP-1 & AsPC-1 \\
\hline O1 & n.d. $^{a}$ & n.d. & S1 & $8.4 \pm 0.3$ & n.d. \\
O2 & $35.2 \pm 0.7$ & $64 \pm 4$ & S2 & $14 \pm 5$ & $75 \pm 3$ \\
O3 & n.d. & n.d. & S3 & $15.8 \pm 0.5$ & n.d. \\
O4 & n.d. & n.d. & S4 & $2.4 \pm 0.2$ & n.d. \\
O5 & n.d. & n.d. & S5 & $24 \pm 9$ & n.d. \\
O6 & n.d. & $57 \pm 2$ & S6 & $18 \pm 6$ & $74 \pm 5$
\end{tabular}

${ }^{a}$ n.d. - not determined in the range of applied concentrations $(1-100 \mu \mathrm{M})$.

necrotic rather than apoptotic death, which was an obvious reason to eliminate it from any further testings.

Apoptotic response in THP-1 cells treated with compound S4 was too drastic when added in the initial concentration range and impeded determination of the dose-response curves and 
computation of $\mathrm{ED}_{50}$ concentration. Therefore, concentrations of S4 had to be reduced to 0.5-30 $\mu \mathrm{M}$ (Fig. S1, ESI $\dagger$ ). Compound $\mathbf{S 4}$, as well as S1, defined bell-shaped dose-response curves with the peak activities at 10 and $50 \mu \mathrm{M}$, respectively (Fig. S2A and $\mathrm{B} \dagger$ ). Considering the percentage of cells stained by Annexin V, the highest activity on THP-1 cells was achieved by $\mathbf{0 2}$ that caused for almost all treated cells to be labeled with both Annexin $\mathrm{V}$ and propidium iodide (PI) in samples subjected to 50,75 and $100 \mu \mathrm{M}$, followed by a drastic decrease in cell death events at already $30 \mu \mathrm{M}$ (Fig. S1, ESI $\dagger$ ). Such activity profile for $\mathbf{O} 2$ was described with nearly vertical linear phase on doseresponse curve typical for drugs with a tight therapeutic window, meaning that there is a narrow range of $\mathbf{O 2}$ concentrations that can achieve desired therapeutic effect while avoiding toxic threshold.

Contrary to the results obtained with THP-1 cells, only four compounds displayed pro-apoptotic activity against pancreatic AsPC- 1 cells (Table 2 and Fig. S3, ESI $\dagger$ ). Interestingly, those four compounds are structural siblings, where $\mathbf{O 2}$ and $\mathbf{O 6}$ are $\mathrm{CHs}$, which analogically corresponds to TCHs $\mathbf{S} 2$ and S6, respectively. Both compounds S6 and particularly $\mathbf{S 2}$ were revealed as less efficient against AsPC- 1 cells compared to THP-1 cells, a result not so surprising since AsPC-1 cells are known as highly resistant to common cytotoxic drugs as well as other cancer stem cell lines are. ${ }^{53,54}$ According to the percentage of Annexin $\mathrm{V}$ positive events, $\mathbf{O} 2$ displayed the highest activity, as previously seen on THP-1 cells, but on AsPC-1 cell line the peak activity starts only at $75 \mu \mathrm{M}$ (Fig. S1 and S3, ESI †). While treatment of THP-1 cells with $\mathbf{O 6}$ resulted in a significant percentage of necrosis as noted above, on AsPC- 1 cells it induced agglomeration of doublestained cells with a very small percentage of Annexin V singlestained events (Fig. S3, ESI†े). A striking lack of gradual introducing of cells from early to late phases of apoptosis seen in AsPC-1 samples treated with $\mathbf{0 2}$ and $\mathbf{0 6}$, is highly indicative as double-stained events were actually belonging to necrotic cells. For this reason, compounds $\mathbf{O 2}$ and $\mathbf{0 6}$ were withdrawn from further investigation on relying mechanisms of apoptotic death in THP- 1 and AsPC- 1 cells.

Concentration-dependent changes in cell cycle distribution suggest on multi-target drugs. The technical solution that was applied in this study implies that both apoptosis and cell cycle analysis were assayed on the very same treated samples and non-treated controls. This allows a highly precise assessment with maximally reduced inconsistencies consequent to separate incubation arrangements. Thus, it highlights any proximate relationship between alterations in cell cycle distribution and incidence of cell death for each concentration of investigated compounds. Cell cycle changes have been evaluated on samples of THP-1 and AsPC-1 cells that were previously confirmed for apoptotic response to the treatments (Fig. S1 and S3, ESI $\dagger$ ).

In general, all evaluated compounds, at some concentration level, did induce accumulation of THP-1 cells in the G1-to-S transition point, while most of them caused concentrationdependent fluctuations in arrangement of cells within phases of mitotic division. As represented in Fig. 1A, treatment of THP-1 cells with $\mathbf{S 1}$ applied in a wide range (from 1 up to $100 \mu \mathrm{M}$ ) resulted in a concentration-dependent fluctuation in cell cycle
A

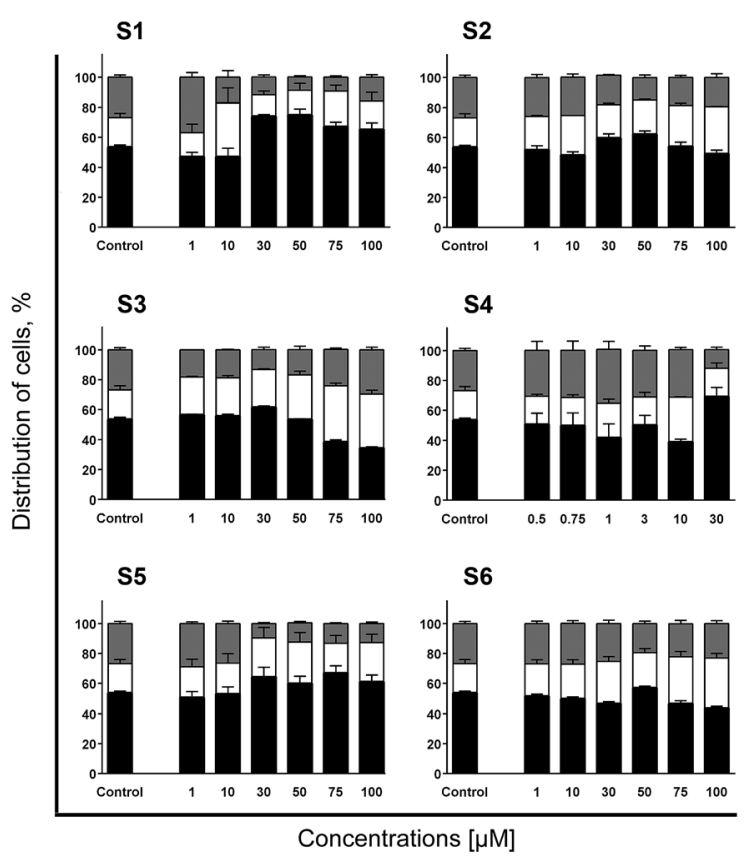

B

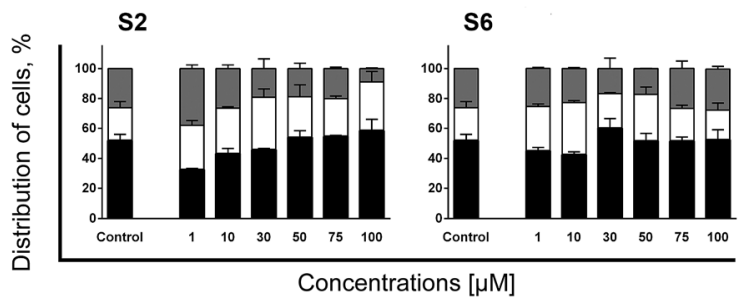

Fig. 1 Distribution within phases of mitotic division of THP-1 cells (A) and AsPC-1 cells (B) determined after $24 \mathrm{~h}$ incubation with investigated compounds. Changes in cell cycle arrangement have been assessed in the same samples previously analyzed for Annexin V/PI (results represented in Fig. S1 and S2, ESI †). Incidences of cells found at the G0/G1 (black), S (white) and G2/M (gray) phases were determined according to non-treated control population. Results are represented as the mean \pm SD of two replicates from independent experiments.

distribution. In the samples treated with its lowest concentration, $\mathbf{S} 1$ stimulated cell accumulation at the G2/M phase. At 10 $\mu \mathrm{M}$ cells were arrested at the G1-to-S transition point accompanied with a significant incidence of apoptotic death, while starting from the sample subjected to the concentration of 30 $\mu \mathrm{M}$, cells shifted to the $\mathrm{G} 0 / \mathrm{G} 1$ block and sustained up to the highest $100 \mu \mathrm{M}$ concentration. Although it might seem that the same mechanism of activity caused cell cycle arrest at the G0/G1 phase, percentage of apoptotic cells and concentrationresponse curve indicate otherwise. The highest percentage of cells at the G0/G1 phase was found in the samples treated with S1 at concentrations of 30 and $50 \mu \mathrm{M}$, which defined the peak of the bell-shaped curve (Fig. S2B †). In the samples subjected to 75 and $100 \mu \mathrm{M}$ magnitude of the G0/G1 block slightly decreased, followed by a notably reduced frequency of apoptotic cells. This decrease in pro-apoptotic activity might indicate that $\mathbf{S 1}$ at higher concentration levels emerged additional mechanism of action that antagonized with the one dominating at concentrations between 30 and $50 \mu \mathrm{M}$. 
Another compound that induced variations in the cell cycle distribution in concentration-dependent manner was S4 (Fig. 1A). Similarly to S1, S4 initially induced THP-1 cells to slightly accumulate at the G2/M phase that was modestly rising concentration-dependently within a range from 0.5 to $1 \mu \mathrm{M}$. The incidence of apoptotic death at those concentration levels was meaningless (Fig. S1, ESI $\dagger$ ). However, starting from the sample treated with S4 at $3 \mu \mathrm{M}$, percentage of cells at the G2/M phase began to decrease followed by accumulation at the G1-to-S transition point and was accompanied with significant increase in incidence of apoptotic death. Finally, at the highest concentration $(30 \mu \mathrm{M})$ a G0/G1 block was recorded together with almost halved percentage of apoptosis as compared to concentration of $10 \mu \mathrm{M}$. It is interesting to emphasize that $\mathbf{S 1}$ and S4 have more similarity in terms of transitive changes within cell cycles than their corresponding bis-TCH S2 and mono-TCH S3 analogues, respectively. Although $\mathbf{S 1}$ and $\mathbf{S 4}$ are not structurally correlated and differ in number of aromatic rings as well as in position of the side chain attached to the hetero-aromatic ring, those molecules share comparable transitive changes within cell cycle distribution. However, that was not the case with their structural counterparts, S2 and S3 (Fig. 1A). Namely, S2 and S3 at lower concentration levels induced accumulation at the G1-to-S transition point, then progress toward a gathering of cells at the $S$ phase. In the case of the compounds with hydroxyl group (S5 and S6), a negligible variations in a cell cycle distribution were seen in the samples treated with concentrations that induced apoptosis in THP-1 cells (Fig. 1A and S1, ESI $\dagger$ ). Both those treatments resulted in accumulation of cells at the G1-to-S transition point at concentration of $30 \mu \mathrm{M}$, which in samples subjected to $\mathbf{S 5}$ was getting intensified following the rise of applied concentration, whereas in cells treated with $\mathbf{S 6}$ a concentration-dependent accumulation of cells at the $\mathrm{S}$ phase was seen.

In AspC-1 cells concentration-dependent fluctuations in cell cycle distribution was seen in samples treated with S2 (Fig. 1B). Accumulation of treated cells at the G2/M phase seen in the samples treated with $\mathbf{S} 2$ at concentration of $1 \mu \mathrm{M}$ was accompanied with low incidence of apoptosis (Fig. S3, ESI $\dagger$ ). At next concentration levels of 10 and $30 \mu \mathrm{M}$, arrest at the $\mathrm{S}$ phase became dominant alteration followed by gradually reduced percentage of cells at the G2/M phase. This switch in cell cycle arrest was accompanied with increased occurrence of apoptotic death. However, rise in percentage of cells at the G0/G1 phase, which started at $50 \mu \mathrm{M}$, coincided with decreased percentage of apoptosis, especially in the sample treated with concentration of $75 \mu \mathrm{M}$. While treatment of THP-1 cells with $\mathbf{S 6}$ triggered accumulation at the $\mathrm{S}$ phase followed by an increased rate of apoptosis (Fig. 1A and S1, ESI $\dagger$ ), in AsPC-1 cells, the same treatment induced the reversed outcome (Fig. 1B and S3, ESI $\dagger$ ). At the concentration range from 10 to $50 \mu \mathrm{M}$ S6 inducted a modest percentage of AsPC-1 cells into apoptosis, whereas at concentrations of 75 and $100 \mu \mathrm{M}$ it resulted in the highest apoptotic response but did not cause any significant alteration in cell cycle distribution when compared to non-treated control.

The classical concept of concentration-response relationship indicates that the interaction between applied drug concentration and caused effect in treated biological model is assumed sigmoidal. Sigmoidal or threshold model of concentration-response curve implies that drugs at low concentrations do not have significant biological effect, while with rise of concentrations the effect linearly increases till the saturation is reached. Increasing number of evidences emerge that threshold model of concentration-related response does not adequately explain all aspects of drug activity. Instead, biphasic or hormetic concentration-response model has been shown as far more appropriate to describe pharmacodynamics features of many drugs used for the treatment of cancer. ${ }^{55-57}$

Despite a large base of published evidences that support biphasic model, to our best knowledge there are only few studies dealing with the underlying cause of non-sigmoidal response, and both had docetaxel as the subject of investigation. ${ }^{\mathbf{5 8 5 9}}$ Hermandez-Vargas et al. ${ }^{59}$ were following changes in cell death, cell cycle, and gene transcription in MCF-7 and MDAMB-231 breast cancer cell lines after treatment with docetaxel. Their results revealed that docetaxel targeted different phases of cell cycle according to drug concentration, whereas a biphasic growth-response curve was in consistence with the existence of at least two different mechanisms of docetaxel's activity. Later on, another group of authors concluded that biphasic doseresponse gained after treatment of prostate cancer cell lines with docetaxel was occurred due to mitotic catastrophe at low concentrations, while apoptosis was the cause of cell death at concentrations higher than $10 \mu \mathrm{M} .{ }^{58}$ Additionally, Szomolay and Shahrezaei ${ }^{55}$ proposed a model where alterations in phosphorylation-dephosphorylation cycles due to different speeds of phosphatase and kinase activity can result in a variety of doseresponse behaviors.

In the current study, we report overlapping and coincidental variations in cell cycle changes followed by altered intensity in apoptotic responses, characterized by biphasic concentrationresponse curves for compounds $\mathbf{S 1}$ and $\mathbf{S 4}$. Other investigated compounds displayed as well concentration-dependent rearrangements of cells within mitotic division, but those were not accompanied with oscillations in apoptotic response and consequential biphasic curve. At the present, we cannot rationally propose bio-molecular reasons for the described results, but we can undoubtedly state that our compounds targeted different phases of cell cycle depending on their concentration. According to those facts, our compounds can be indicated as those with polypharmacological profiles, which implies on a single drug that is acting on multiple cellular targets. ${ }^{60}$ This type of drugs offers several advantages over standard drug combination and the main of them include easer dose titration and evasion of serious drug interactions regarding their toxicological profiles, metabolism and excretion. Therefore, recognition of biological molecules targeted by current compounds will be the subject of our further investigations.

Positive relationship between structural similarity and caspases dependency of apoptotic death. Relaying on results of pro-apoptotic activity, which showed superiority of TCHs, the focus of our attention in the course of investigation on caspases activity was directed toward assessment of structure-activity relationship between pairs of corresponding mono- and bis- 
TCHs. Firstly, we wanted to define was the apoptosis induced by our compounds caspase-dependent or not. For that matter, we applied two assays with intention to determine to which extent apoptosis was dependent upon caspases' activation, as well as which of the two main caspases pathways were activated due to the particular treatment. Co-incubation with pan-caspase inhibitor during $6 \mathrm{~h}$ incubation provided the information on the extent of caspases' implication in the process of apoptotic death induced by investigated compounds. Comparison of the percentages of apoptotic and necrotic events between samples co-treated with Z-Val-Ala-Asp (OMe) fluoromethylketone (Z-VAD-fmk) and those treated with investigated compound only revealed the amplitude of inhibited apoptotic deaths, as well as consequential shifting in the incidence of necrosis, both as a result of interrupted caspases cascades. Despite the fact that caspases have no role in the process of necrotic death, there are two ways in which co-incubation with Z-VAD-fmk can alters the incidence of necrotic events in respect to compound singletreated samples. First, increased percentage of necrotic cells in the Z-VAD-fmk co-treated sample reveals that the investigated compound generated forceful pro-apoptotic stimuli which could not be executed due to aborted activation of caspases pathways and cells had to end in necrosis. Second, reduced percentage of necrotic cells in Z-VAD-fmk co-treated samples indicates that necrosis in compound single-treated samples came out as a result of aponecrosis, while the mechanism responsible for triggering of apoptotic death was not that assertive as in the previous example and cells were restrained from slipping into necrosis. Although recorded change in incidences of apoptosis and necrosis induced by co-treatment with Z-VAD-fmk for the same compound are not algebraically compatible, it is recommended to follow alterations of the both types of cell death in order to get more accurate insight into extent of caspase-dependency during the process of apoptotic death.

Evident correlation between structure and degree of caspase dependency of apoptotic process in THP-1 cells induced by the treatment with investigated compounds was found in two pairs of mono- and corresponding bis-TCHs (Fig. S4A, ESI $\dagger$ ). There were almost the same percentages of inhibited apoptotic events by co-incubation with Z-VAD-fmk between counterparts $\mathbf{S 3}$ and S4 ( $25 \pm 8 \%$ and $24 \pm 8 \%$, respectively), as well as between $\mathbf{S 5}$ and S6 ( $45 \pm 12 \%$ and $42 \pm 12 \%$, respectively), together with strong compliance regarding proportions of inhibited early and late apoptotic events. However, while in the case of S5 and S6 similarity was evident also in relation of inhibited incidence of necrotic deaths ( $34 \pm 4 \%$ and $42 \pm 12 \%$, respectively), Z-VAD-fmk in the samples subjected to $\mathbf{S 3}$ drastically increased the percentage of necrotic events compared to the samples treated with S4 $(-221 \pm 65 \%$ and $-4.0 \pm 0.6 \%$, respectively). The only pair of mono- and bis-TCHs that did not show a strong equivalence regarding dependency in caspases activities and apoptosis is $\mathbf{S 1}$ and S2. While co-incubation with Z-VAD-fmk and S2 resulted with poorly reduced incidence of apoptotic cells $(28 \pm$ $14 \%$ ), the addition of pan-caspase inhibitor almost completely inhibited apoptosis promoted by the treatment with $\mathbf{S 1}(81.2 \pm$ $0.3 \%$ ). Incompatibility regarding induction of caspases activation between these two compounds was also determined concerning influence of Z-VAD-fmk on the frequency of necrotic events. It is obvious that contrary to hydroxyl derivate S5, another two monoTCHs, S1 and S3, have substantially challenged survival of THP-1 cells thus those had to end in necrosis, which was not the case with their bis-TCH counterparts.

Interestingly, apoptosis in AsPC-1 cells due to the treatment with S2 revealed as more caspase-dependent (43 $\pm 16 \%)$ compared to its effect on the THP- 1 cells, with necrosis almost equivalently reduced in both cell lines by the treatment with ZVAD-fmk (Fig. S4B, ESI $\dagger$ ). Quite contrary, process of apoptotic death triggered by $\mathbf{S 6}$ in AsPC-1 cell line was less caspasedependent $(32 \pm 4 \%)$ than in THP-1 cells, together with slightly stimulated necrotic events. These results indicate those two compounds most probably drove THP-1 and AsPC- 1 cells to apoptotic death by different mechanisms, or in other words, their activities were phenotype specific.

Activation of caspase-8 was a prevailing trend in treated cells. Two main caspase pathways are involved in the process of apoptotic death in eukaryotic cells. ${ }^{61}$ The extrinsic pathway, mediated by caspase-8, is activated either by triggering of specific transmembrane receptors or by endoplasmic reticulum stress. ${ }^{62}$ The intrinsic pathway, mediated by caspase-9, is activated as a result of bioenergetics and metabolic catastrophe. The assay we applied enables to concomitantly follow activation of those two caspase pathways in the same sample, where percentage of cells with single activated caspase-8 or -9 in regard to non-treated control indicates on which of these pathways were stimulated upstream.

Strong correlation in apoptosis caspase-dependency found between mono- and bis-TCHs has been repeated in the assay of caspase- 8 and -9 activation. The most impressive is almost the same pattern in assortment of cells with activated calspase-8, -9, or both between samples treated with $\mathbf{S 3}$ and $\mathbf{S 4}$ (Fig. 2A). It is important to accentuate that these two compounds significantly suppressed caspase-9 activation, which strongly indicates that apoptosis induced in THP-1 cells by $\mathbf{S 3}$ and $\mathbf{S 4}$ has not been driven by intrinsic apoptotic pathway. Prominent similarity was clearly obvious for another pair of mono- and bis-TCHs. Namely, $\mathbf{S 1}$ and $\mathbf{S 2}$ were the only compounds that displayed diverse level of caspase-dependency on THP-1 cells (Fig. S4A, ESI $\dagger$ ), while here both induced significant increase in percentage of cells with activated caspase-8 only and moderately reduced percentage of cells with single activated caspase-9 (Fig. 2A). The addition of hydroxyl group on aromatic ring resulted in a slight difference in caspases' activation between samples treated with mono- and bis-TCHs S5 and S6 respectively. Compound $\mathbf{S 5}$ was the only one not markedly increasing the percentage of cells with activated caspase-8, but rose proportion of cells with single activated caspase- 9 although not significantly compared to non-treated control.

However, another repeating occurrence became evident when comparing the effects of mono- and bis-homologs: in all samples subjected to bis-TCHs, the percentages of cells expressing both caspase- 8 and -9 were considerably higher compared to samples treated with their mono-counterparts (Fig. 2A). A cross talk that exists between extrinsic and 
A

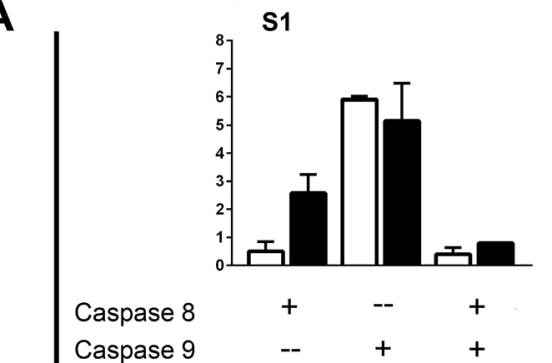

intrinsic apoptotic pathways allows them to activate each other. Thus, active caspase- 9 cleaves and further activates caspase- 3 that subsequently in a feedback amplification loop activates caspase- $8 .^{63}$ Otherwise, activated caspase-8 via bid processing propels mitochondrial outer membrane permeabilization with cytochrome c release. The latter is involved in formation of apoptosome together with apoptotic protease activating factor 1 (APAF1), ATP and pro-caspase-9, which results in the activation of caspase-9. ${ }^{61}$ As was reviewed above, with exception of compound S5, all mono- and bis-TCHs primarily triggered activation of caspase-8, but the percentages of cells with both activated caspases in samples treated with $\mathbf{S 1}$ and $\mathbf{S 3}$ were on the level of non-treated control that makes quite possible these two ligands interfered with the cross-talk activation of caspase9. On the other hand, in THP-1 cells treated with S5 and S6, almost the same percentages of cells with both active caspases were determined, while in cells subjected to S5 caspase-8 was activated subsequently to caspase-9.

Likewise assayed in THP-1 cells, activation of caspase-8 dominates in AsPC-1 samples treated by bis-TCHs S2 and $\mathbf{S 6}$ (Fig. 2B). However, $\mathbf{S} 2$ in AsPC-1 cells also initiated activation of caspase-9 independently of caspase-8, while $\mathbf{5 6}$ reduced
B

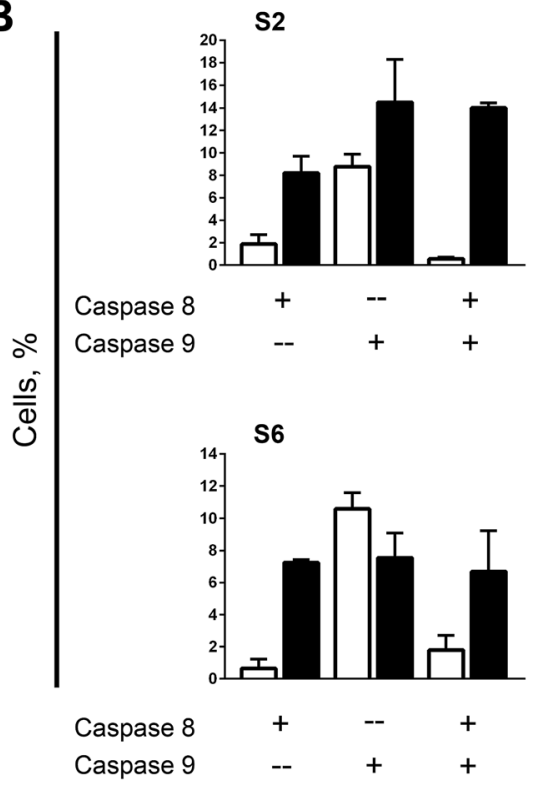

$\square$ Non-treated cells
$\square$ Treated cells caspase-9 activity compared to non-treated control. These results reinforce the assumption stated above on phenotype specific mechanisms of $\mathbf{S 2}$ and $\mathbf{S 6}$ activities.

Mono-TCHs revealed higher pro-oxidant activity. Currently, there are two opposing therapeutic strategies that employ ROS to beat the cancer. One of them supports the use of ROS-scavenging compounds that are capable to abolish ROS signaling and therefore inhibit tumor growth. However, apart from experimental evidences which shown that antioxidants decreased antitumor activity of anticancer agents such as paclitaxel, bortezomib and radiation therapy, ${ }^{64-66}$ more importantly are results of clinical trial which revealed that use of several antioxidants were associated with increased cancer evidence. ${ }^{67}$ The other approach implies the use of agents that increase ROS generation. Interestingly, results of preclinical studies with ROS-generating agents showed selective antitumor toxicity. ${ }^{65,68,69}$

Mitochondria are a significant source of ROS, together with endoplasmic reticulum and peroxisomes. ${ }^{70}$ Here, we have investigated pro-oxidant properties of all our compounds that induced apoptotic cell death in THP-1 and AsPC-1 cell lines, by following their ability to induce superoxide formation in mitochondria using MitoSOX Red fluorescent tracker. Although 
selectivity of MitoSOX Red toward superoxide radicals has been questioned by Zielonka and colleagues, ${ }^{71,72}$ other authors demonstrated its specificity and confirmed ability for sitespecific detection of mitochondrial superoxides. ${ }^{73,74}$

Basal production of ROS was very similar in the both cell lines when expressed as percentage of ROS-producing cells, (5.4 $\pm 0.6 \%$ for THP- 1 and $8.4 \pm 0.3 \%$ for AsPC- 1 ). In THP- 1 cells, considerably higher pro-oxidative activity was obtained after mono-TCHs $\mathbf{S 1}$ and $\mathbf{S} 3$ treatments as compared to their bisstructural analogues S2 and S4 (Fig. 3A). Less striking discrepancy in ROS-generating ability was revealed for S5 and S6. Considering structural features, S1, S3 and S5 have highly reactive $-\mathrm{NH}-\mathrm{NH}_{2}$ group that is probably in relation to their increased pro-oxidant capacity. On the other hand, $-\mathrm{OH}$ group attached to the quinoline ring of $\mathbf{S 6}$ contributed to a ROSgenerating capacity in comparison to other bis-TCHs S2 and S4. However, two hydroxyl groups in $\mathbf{S 6}$ could not raise the ROSproducing potential to the level of mono-TCHs. Moreover, quite intriguing results were obtained with treatment of AsPC- 1 cells by $\mathbf{S} \mathbf{2}$ and $\mathbf{S 6}$ as they were the only TCHs that revealed proapoptotic activity on this cell line (Fig. 2B). While there was almost no difference comparing percentages of ROS-positive cells in THP-1 and AsPC-1 samples treated with S6, treatment of AsPC-1 cells with $\mathbf{S 2}$ resulted in significantly higher amplitude of ROS production than in THP-1 cell line. This particular outcome with $\mathbf{S 2}$ cannot be put in relation to its structure, but only as another proof for phenotype-specific activity with no rational explanation that can be given so far.

Although $\mathbf{O 2}$ was excluded from detailed analysis on mechanisms involved in apoptotic death, we chose here to explore its pro-oxidant activity and compare these results with those of its structural analogue $\mathbf{S 2}$. In THP-1 cells $\mathbf{O 2}$ induced a four-fold higher ROS production than S2 (Fig. 3A and C). From the point of structure-activity relationship, oxygen placed in $\mathbf{0 2}$ instead of sulfur in $\mathbf{S 2}$ may be considered as the cause for increased pro-oxidant activity of $\mathbf{0 2}$. On the other hand, $\mathbf{0 2}$, as well as S6, gave the equivalent result on AsPC-1 and THP-1 cells (Fig. 3A-C). This outcome additionally underlines phenotypespecific pro-oxidant activity of S2, which deserves further detailed experimental analysis. Furthermore, by comparing mitochondrial ROS-generating activity and apoptotic responses in THP-1 and AsPC-1 cell lines (Fig. S1 and S3, ESI †), the lack of clear correlation between these two cellular events become obvious. Compounds S2, S4 and S6, which were strong proapoptotic inducers compared to their mono-TCHs counterparts, reveal here less pro-oxidant activity. Compound $\mathbf{0 2}$ inducing high percentage of ROS-positive cells on both cell lines triggers necrotic cell death and not apoptosis. Finally, significant discrepancy in mitochondrial ROS production found in THP-1 and AsPC-1 cells treated with S2, is in reverse proportion with incidence of apoptotic death. The only interdependency in relation of high ROS generation was seen in AsPC-1 cells treated with $\mathbf{S} 2$ that also displayed accelerated activation of caspase-9, previously confirmed as associated mechanisms by which oxidative stress initiates apoptotic death. ${ }^{75}$ Prevailing activation of caspase-8 in the majority of investigated samples (Fig. 2), together with the fact that treatment with $\mathbf{S 2}$ induced poor
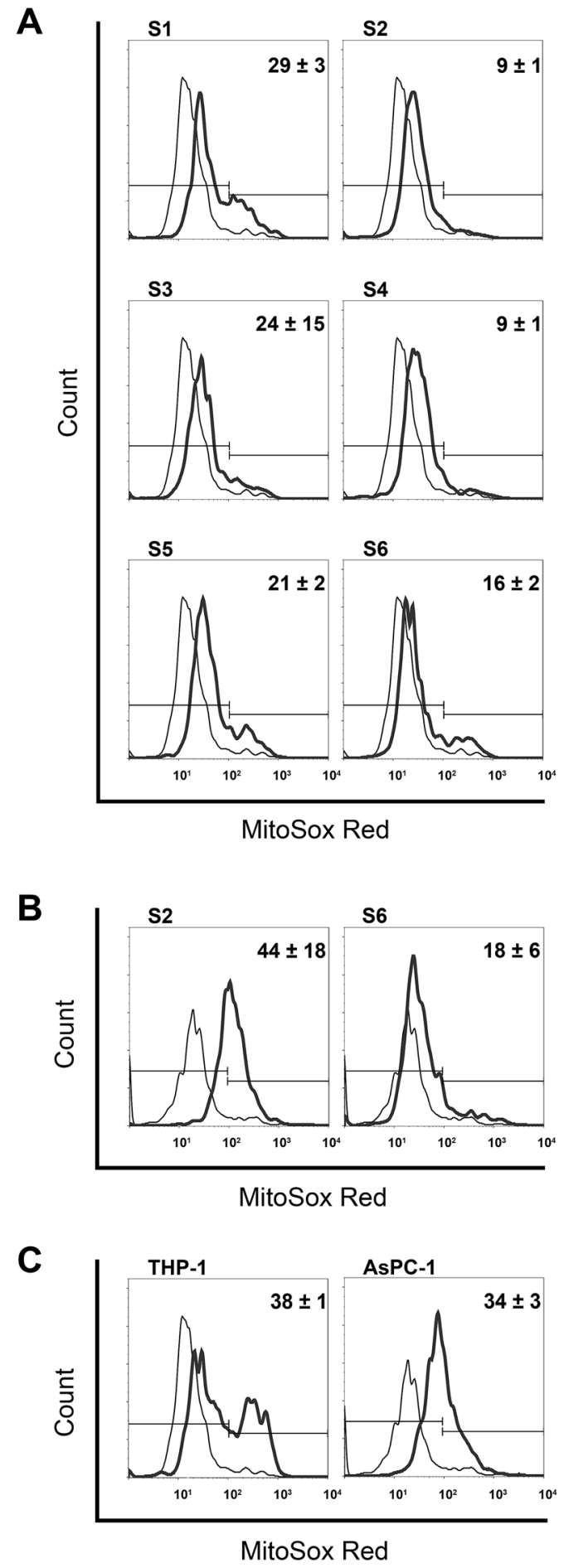

Fig. 3 Mitochondrial superoxide radical production in THP-1 cells (A), AsPC-1 cells (B), and in both cell lines subjected to O2 (C). All investigated compounds were added in concentration of $50 \mu \mathrm{M}$ during $6 \mathrm{~h}$ of incubation. Histograms present distribution of MitoSox Red positive cells in non-treated controls (thin line) and treated cells (thick line) with the mean \pm SD percentage of cells positive for ROS in two treated replicates from independent experiments.

apoptotic response in AsPC-1 cells, strongly indicates that mitochondrial ROS formation did not play an important role in triggering apoptosis in THP-1 and AsPC-1 cells. 
Bis-TCHs revealed ability to induce reprogramming of CSC phenotype in AsPC-1 cells. For the use of drugs in combination for cancer treatment, among the leading reasons, the first remains to avoid fast development of tumor resistance. However, acquired resistance occurs over time for almost every drug, unless the therapy is curative. Development of insusceptibility to treatment relies on intra-tumor heterogeneity where resistant sub-clones drive cancer progression, as previously explained above. The discovery that some of our compounds induce a strong apoptotic response in the used CSC model, together with their ability to target different phases of cell cycle in a concentration-dependent manner, strongly indicated a multi-target mode of activity. Thus, we wanted to test their potential to induce differentiation in AsPC-1 cells. For this experiment, we chose compounds $\mathbf{S 2}$ and S6, the two inducing apoptosis in AsPC-1 cells. Additionally, compound S4 was included as the only molecule (among three bis-TCHs) that did not reveal pro-apoptotic activity on these CSCs.

AsPC-1 cells were incubated over $72 \mathrm{~h}$ with low concentrations of the investigated compounds, and afterwards stained with anti-CD44s-FITC in order to follow possible changes in expression of this stemness CSCs surface marker. ${ }^{76,77}$ CD44 is a transmembrane glycoprotein that serves as a receptor for various components of extracellular matrix. ${ }^{78,79}$ Its most important roles include intermediation in cell-cell and cellmatrix interactions, as well as cancer cell migration. Thus, CD44 binding regulates CSCs survival, self-renewal, and chemoresistance. ${ }^{79,80}$ Our experimental results were analyzed regarding two parameters: percentage of positive CD44 cells, and the median fluorescent intensity (MFI) expressed in arbitrary units (AU) for CD44-positive cells subgroup. Thus computed MFI represents median incidence of CD44 expression per cell, irrespectively of size of CD44-positive population.

In non-treated AsPC-1 samples, $89 \pm 3 \%$ of cells were expressing CD44 with a MFI of $3416 \pm 43$ AU. In cells subjected to S2 and S6 at concentration of $10 \mu \mathrm{M}$, a slight reduction of the number of CD44-positive subpopulation was recorded (Fig. S5A and $\mathrm{B}, \mathrm{ESI} \dagger)$. This effect was accompanied with decrease in MFI to $2918 \pm 91 \mathrm{AU}$ and $2396 \pm 167 \mathrm{AU}$ for the samples treated with S2 and S6, respectively. These changes in MFI signify that the applied treatments down-regulate the number of CD44 receptors per cell. At concentration of $1 \mu \mathrm{M}, \mathbf{S} 2$ and S6 significantly dropped the percentages of CD44-positive cells. Compound S6 accomplished the best response, whereas MFI values were still a bit higher (1876 $\pm 120 \mathrm{AU})$ compared to samples treated with $\mathbf{S 2}$ $(1711 \pm 42 \mathrm{AU})$. On the contrary, compound S4, the one that did not achieve apoptotic response in AsPC-1 cells, now revealed an ability to induce their differentiation with inverse concentrationdependency matching to the two other compounds (Fig. S5C, ESI $\dagger$ ). It is interesting to note that $\mathbf{S 4}$ at $10 \mu \mathrm{M}$ accomplished the greatest down-regulation of CD44 expression according to MFI values $(1522 \pm 48 \mathrm{AU})$. These results suggest that our compounds may have the ability to stimulate reprogramming of AsPC-1 cells independently of any pro-apoptotic activity, and thus should be further studied by following the expression of other CSC phenotype markers like Oct4, Nanog or Sox $2 .{ }^{81}$
Activity on tumor spheroids. Tumor spheroids are 3D culture models that in vitro mimic in vivo malignant tissue in respect to multiple parameters such as drug concentration, molecular weight, kinetics, charge, solubility, diffusion, oxygenation, metabolism, and sequestration..$^{82}$ As they are, spheroids serve as a valuable screening platform for advanced evaluation of anticancer drug effectiveness with exception of their influence on response of the immune system (also the case for xenografts in nude mice) and on angiogenesis. Most spheroids derived from CSCs are compact globes with concentric zones clearly distinguished within, which growing is characterized by regular increase in diameters. ${ }^{83}$ However, AsPC-1 cells create spheres of irregular shape without recognizable zones inner their structure. ${ }^{46}$ Their growth is erratic, does not primarily comprise the enlargement in diameters but rather formation of satellite spheres that highly look like metastatic propagation. For that reason, growth recording in our study of non-treated or treated spheroids has been performed by computation and summation of surface areas for all tumor masses in each well.

Activities of four compounds, which did induce cell death in the 2D AsPC-1 model irrespectively of apoptosis or necrosis, were evaluated (Fig. S3, ESI $\dagger$ ). The 3D spheres were treated for eight days, and compounds were tested in three concentrations (1, 10 and $100 \mu \mathrm{M})$. Here are reviewed only results for concentrations that at the day 8 achieved a reduction of spheroid size when compared to day 0 (growth rate $<1$, Fig. 4 ).

Growth of non-treated spheres recorded a linear rate, with a maximal increase of $1.5 \pm 0.3$ fold at day 8. Compound $\mathbf{O 6}$ was the only one effective in two evaluated concentrations. While at concentration of $10 \mu \mathrm{M}$ O6 successfully inhibited growth of tumor mass, at $100 \mu \mathrm{M}$ it reduced tumor mass to a half of its initial size after six days of incubation. The second most successful treatment was at $100 \mu \mathrm{M}$ for $\mathbf{O} 2$ as the only compound which activity was described with a steadily downhill growth rate curve, with the tumor sizes at the day 8 equal to those subjected to $\mathrm{O6}$ at $100 \mu \mathrm{M}$. It is important to notice that both $\mathbf{O 6}$ and $\mathbf{O} 2$ were withdrawn from further investigations due to results of Annexin V/PI staining, considering both of them induced necrotic death, a situation that in vivo induce inflammation thus not suitable for any putative drug. Furthermore, in 2D model samples treated with $\mathbf{O 2}$, at the same concentration, more than $89 \%$ of cells were double-stained, while 06 was relatively less efficient. Similarly to those treated with $\mathbf{O 2}$, spheres exposed to S6 were continually losing size until day 6. The most surprising was the activity of $\mathbf{S 2}$, a compound which on $2 \mathrm{D}$ model at $100 \mu \mathrm{M}$ triggered apoptotic death in less than $25 \%$ of the population. On $3 \mathrm{D}$ culture, $\mathbf{S 2}$ displayed a delayed response, which was documented with slight gain in size of treated spheres during the first four days, that was followed by significant collapse of their masses undoubtedly caused by significant incidence of cell death. Therefore, for S2, according to results on 2D model, it might be proclaimed as compound of no interest regarding treatment of AsPC-1 cells. Here S2 revealed as almost equally effective as tumor growth inhibition of S6. This result is an excellent testimonial for the use of 3D cultures in drug screening as it is more accurate and closer to in vivo situation. 
A

\section{$\begin{array}{lllll}\text { Day } 0 & \text { Day } 2 & \text { Day } 4 & \text { Day } 6 & \text { Day } 8\end{array}$}

Control

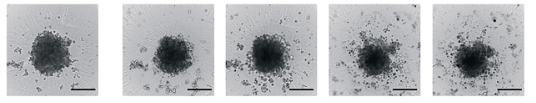

$\mathrm{O} 2[100 \mu \mathrm{M}]$
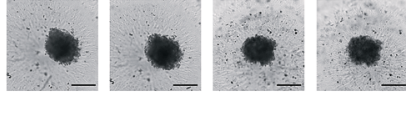

$06[100 \mu \mathrm{M}]$
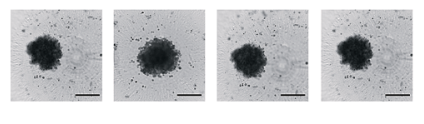

$06[10 \mu \mathrm{M}]$
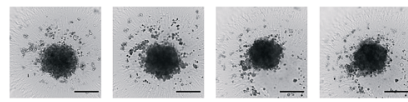

$\mathrm{S} 2[100 \mu \mathrm{M}]$
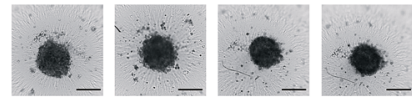

S6 $[100 \mu \mathrm{M}]$
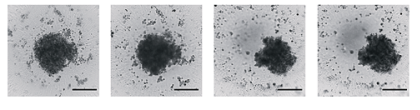

B

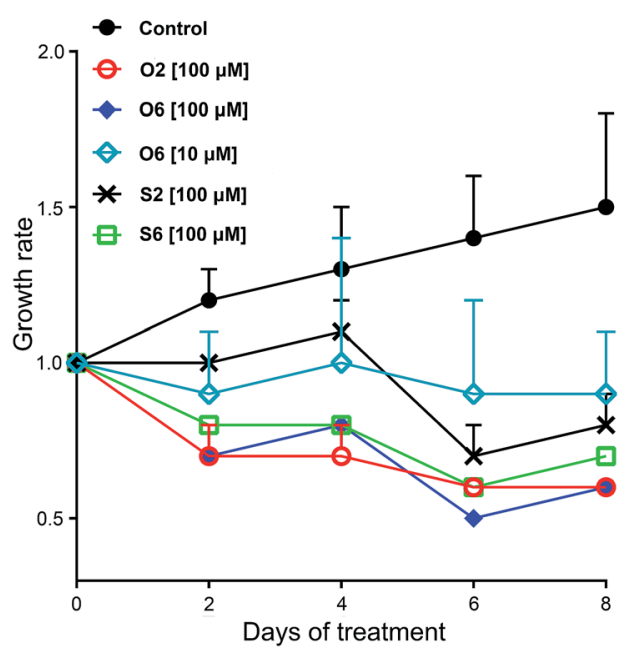

Fig. 4 Changes in size and morphology of AsPC-13D culture over the 8 day treatment period (A). Images have been acquired every other day, starting from day 0 on the Celigo imaging cytometer using Celigo software. Scale bar: $500 \mu \mathrm{m}$. Growth rates of non-treated and treated AsPC-1 spheroids over the time of experiment (B).

\section{Interaction between S2 and human serum albumin (HSA)}

HSA is well known for its ligand binding capacity and repository for an extraordinarily diverse range of molecules which makes it an important factor in the pharmacokinetic behavior of many drugs by affecting their efficiency and rate of delivery. Its feature to accumulate in solid tumors raises interest of medicinal chemists to explore ability of newly synthesized compounds to bind to and use HSA as a carrier, and yields the rationale for developing the albumin-based drug delivery systems for tumor targeting drugs. ${ }^{84}$ Here we explored performed experimental and docking analysis protocol to obtain information on selected TCH S2 interaction with HSA.

Criterions used to choose the compound for evaluation of HSA binding were pro-apoptotic activity on both investigated cell lines and lipophilicity as one of the most important factors involved in the extent of drug binding. ${ }^{85}$ Although $\log P$ was argued as not reliable physicochemical descriptor to distinguish strong and weak binders among diverse ligands ${ }^{86}$ its higher value defined for $\mathbf{S 2}$ was the rational to investigate its binding properties rather than for S6 (Table S5, ESI†). Binding of S2 to HSA was studied by UV/Vis spectroscopy. After the addition of HSA to the solution of S2, blue shift of absorption maximum was observed (Fig. 5). More details about the HSA-S4 binding were obtained from fluorescence titration experiments and molecular docking.

Fluorescence spectroscopy. The changes in emission spectrum of HSA during titration with the increasing amount of S2 are shown in Fig. 6. Significant decrease of HSA fluorescence intensity (fluorescence quenching) is observed during titration, with the blue shift of maximum emission at $\sim 340 \mathrm{~nm}$. The blue shift of the maximum emission wavelength indicates that the

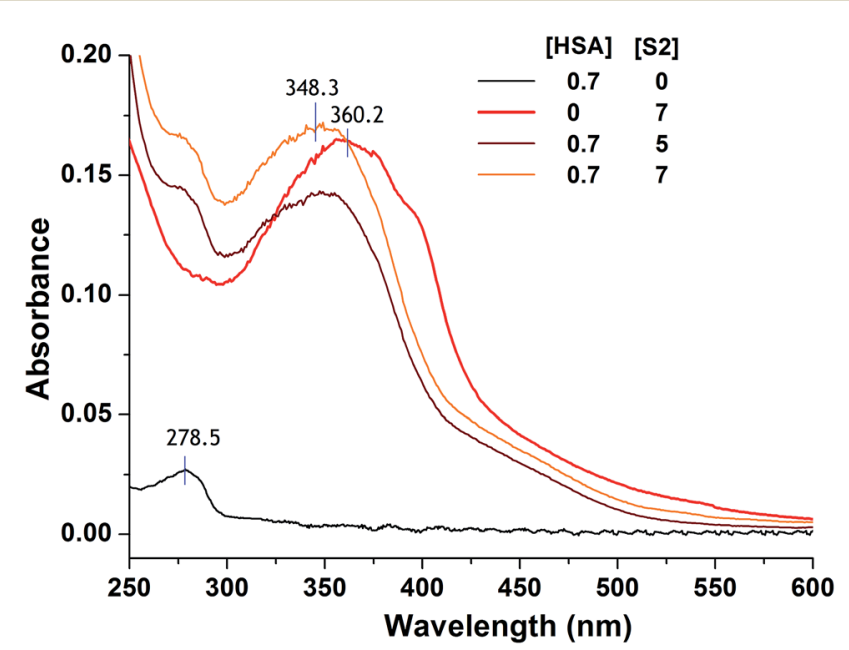

Fig. 5 Changes in absorption spectrum of S2 after addition of HSA. All concentrations are given in $\mu \mathrm{M}$. Spectra are recorded in $30 \mathrm{mM}$ phosphate buffered saline (PBS), pH 7.36 .

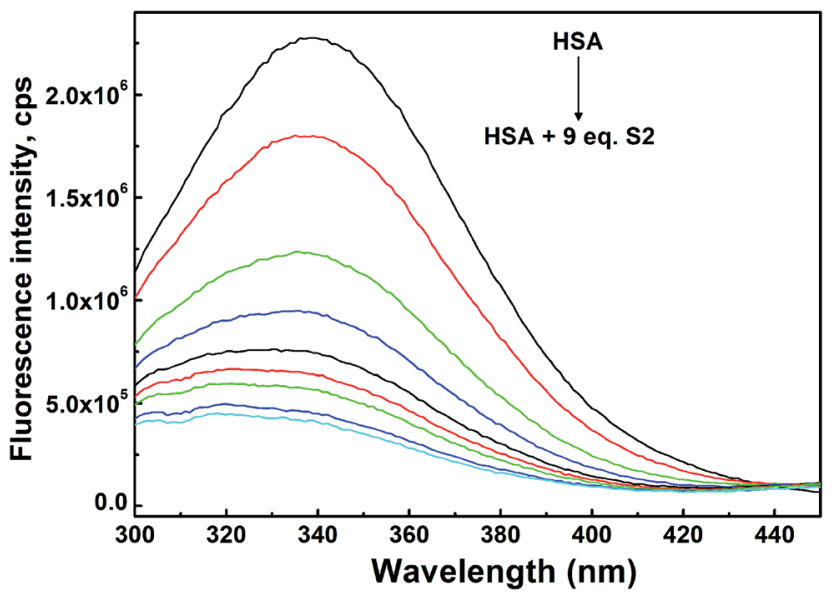

Fig. 6 Changes in fluorescence emission spectra of $\mathrm{HSA}\left(c=7 \times 10^{-7}\right.$ M) upon addition of $S 2$ in following concentrations: $(0.0 ; 0.35 ; 0.7 ; 1.4$; $2.1 ; 2.8 ; 3.5 ; 4.9,6.3) \times 10^{-6} \mathrm{M} ; T=310 \mathrm{~K} ; 30 \mathrm{mM} \mathrm{PBS}, \mathrm{pH}=7.4$. 
microenvironment around Trp214 is altered as HSA-S2 complex is formed.

With the increasing amount of quencher, results may deviate from the linearity due to instrumental inner filter effect. This effect was removed applying Lakowicz procedure, eqn (1).

$$
F_{\text {corr }}=F_{\text {obs }} \times 10^{\frac{A_{\mathrm{ex}}+A_{\mathrm{em}}}{2}}
$$

where $F_{\text {corr }}$ and $F_{\text {obs }}$ are corrected and observed fluorescence intensities, and $A_{\mathrm{ex}}$ and $A_{\mathrm{em}}$ are absorbancies at the excitation and emission wavelengths, respectively. ${ }^{87}$ Corrected fluorescence intensities were used for all calculations.

Fluorescence data were processed using double log plot, according to the eqn (2).

$$
\log \frac{F_{0}-F}{F}=\log K_{\mathrm{b}}+n \log [Q]
$$

where $F_{0}$ and $F$ have the same meaning as in previous equation; $K_{\mathrm{b}}$ is binding constant, and $n$ is the number of independent binding sites for molecule. Linear dependence for quenching data recorded at $310 \mathrm{~K}$ is shown in Fig. 7 , and the results of linear fit for three temperatures are given in Table 3.

Fluorescence quenching is classified as static or dynamic. Dynamic quenching is highly dependent upon diffusion. Higher temperatures result in faster diffusion and hence larger values for biomolecular quenching constant. On the other hand, higher temperatures will typically result in the dissociation of weakly bound complexes, and therefore decrease the biomolecular quenching constant in static process. The $K_{\mathrm{b}}$

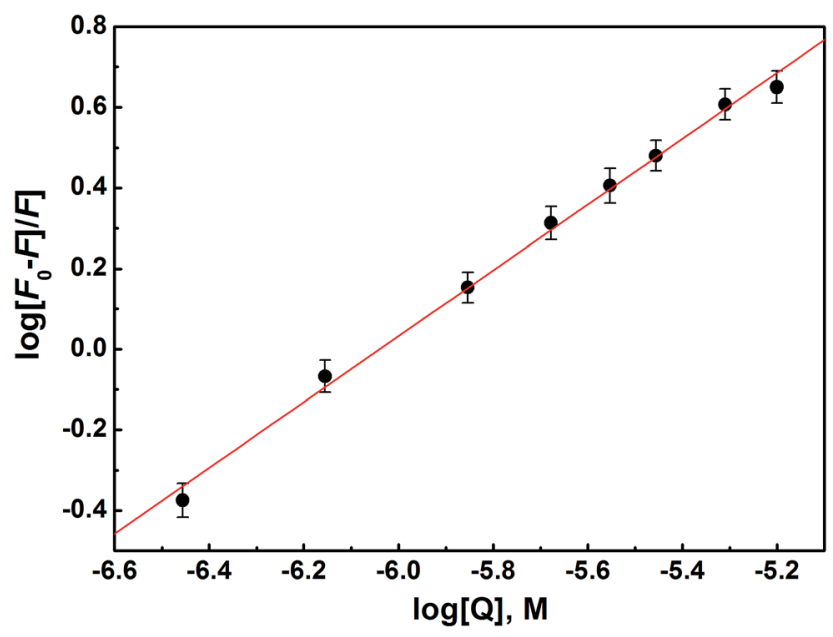

Fig. 7 Double-log plot for determination of binding constant $K_{\mathrm{b}}$, and the number of binding sites $n$ for HSA-S2 interaction.

Table 3 Binding constants $\left(K_{b}\right)$ and the number of binding sites for binding of S2 to HSA at three temperatures

\begin{tabular}{lllll}
\hline$T(\mathrm{~K})$ & $K_{\mathrm{b}}\left(\mathrm{M}^{-1}\right) \times 10^{4}$ & $\log K_{\mathrm{b}}$ & $n$ & $r^{2}$ \\
\hline 293 & $8.5 \pm 2.2$ & $4.9 \pm 0.1$ & $0.82 \pm 0.02$ & 0.995 \\
301 & $6.1 \pm 2.8$ & $4.8 \pm 0.2$ & $0.78 \pm 0.04$ & 0.986 \\
310 & $4.6 \pm 0.8$ & $4.7 \pm 0.1$ & $0.77 \pm 0.01$ & 0.998
\end{tabular}

value decreases with the increase of temperature, which is an indication of static quenching mechanism.

Compound $\mathbf{S 2}$ binds to approximately one binding site, as suggested with the value of $n$. The $\log K_{\mathrm{b}}$ is in the range optimal for biologically active compounds. ${ }^{\mathbf{8 - 9 0}}$ These results suggest that $\mathbf{S} 2$ strongly binds to HSA, so it can be effectively carried and stored in the human body.

Thermodynamic parameters of binding. The enthalpy $(\Delta H)$ and entropy change $(\Delta S)$ during the binding of small molecule to protein can be determined measuring the binding constants at several temperatures, and following the Van't Hoff eqn (3):

$$
\ln K_{\mathrm{b}}=-\frac{\Delta H}{R T}+\frac{\Delta S}{R}
$$

where $R$ is the universal gas constant, $T$ is the temperature (in $\mathrm{K})$, and $K_{\mathrm{b}}$ is the binding constant at the corresponding temperature. Results are shown in Fig. 8 and Table 4.

According to Ross' view, ${ }^{\mathbf{9 1}}$ the signs and magnitudes of thermodynamic parameters for protein reactions can account for the main forces contributing to protein stability. From the thermodynamic stand-point, $\Delta H>0$ and $\Delta S>0$ implies a hydrophobic interaction, $\Delta H<0$ and $\Delta S<0$ reflects the van der Waals force or hydrogen bond formation and $\Delta H<0$ and $\Delta S>$ 0 suggesting an electrostatic force.

The negative enthalpy and negative entropy indicate that the van der Waals forces or hydrogen bonding are dominant for HSA-S2 binding. Process is enthalpically driven, and hydrogen bonds between HSA and S2 are the most important intermolecular forces.

Molecular docking of S2 with HSA. To explore the binding mode of $\mathbf{S 2}$ to HSA, docking of $\mathbf{S 2}$ into the sites IB, IIA and IIIA

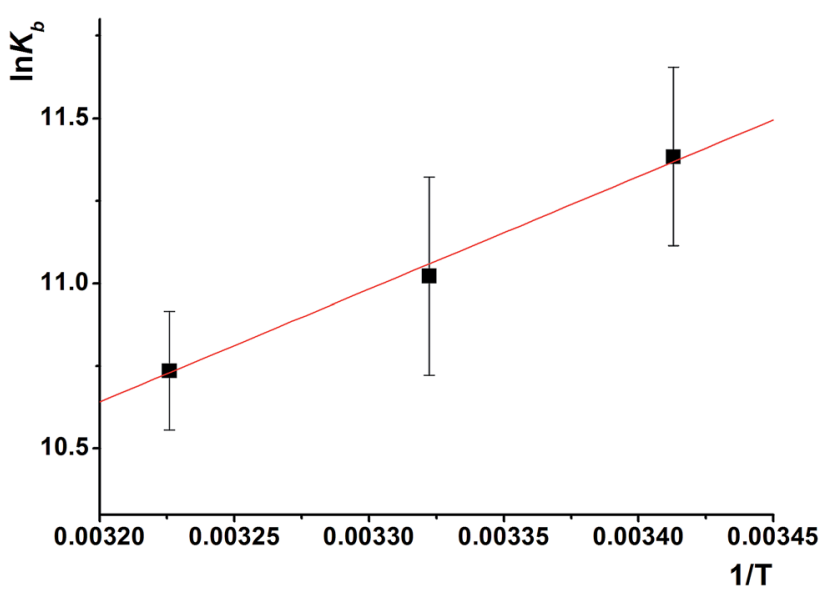

Fig. 8 The plot of $\ln K_{\mathrm{b}}$ vs. $1 / T$ for the interaction of S2 with HSA.

Table 4 Thermodynamic parameters of S2 binding to HSA

\begin{tabular}{lllll}
\hline$T(\mathrm{~K})$ & $\ln K_{\mathrm{b}}\left(\mathrm{M}^{-1}\right)$ & $\begin{array}{l}\Delta G \\
(\mathrm{~kJ} \mathrm{~mol}\end{array}$ & $\begin{array}{l}\Delta H \\
\left(\mathrm{~kJ} \mathrm{~mol}^{-1}\right)\end{array}$ & $\begin{array}{l}\Delta S \\
\left(\mathrm{~J} \mathrm{~mol}^{-1} \mathrm{~K}^{-1}\right)\end{array}$ \\
\hline 293 & 11.38 & 27.731 & 28.731 & -3.55 \\
301 & 11.02 & 27.584 & & \\
310 & 10.74 & 27.670 & &
\end{tabular}


was performed. The binding energies are given in Table 5 . Compound $\mathbf{S} 2$ favorably interacts with the binding site IIA.

The most favorable docking solution for each binding site is shown in Fig. 9. S2 has many polar interactions within the site IIA of HSA. It makes hydrogen bonds with the residues His242

Table 5 Docking scores of S2 into the three sites of HSA

\begin{tabular}{ll}
\hline $\begin{array}{l}\text { Binding site } \\
\text { (PDB code) }\end{array}$ & $\begin{array}{l}\text { Binding affinity } \\
\left(\mathrm{kcal} \mathrm{mol}^{-1}\right)\end{array}$ \\
\hline IB (4LB2) & -9.0 \\
IIA (3LU7) & -11.0 \\
IIIA (2BXE) & -9.7 \\
& \\
\hline
\end{tabular}
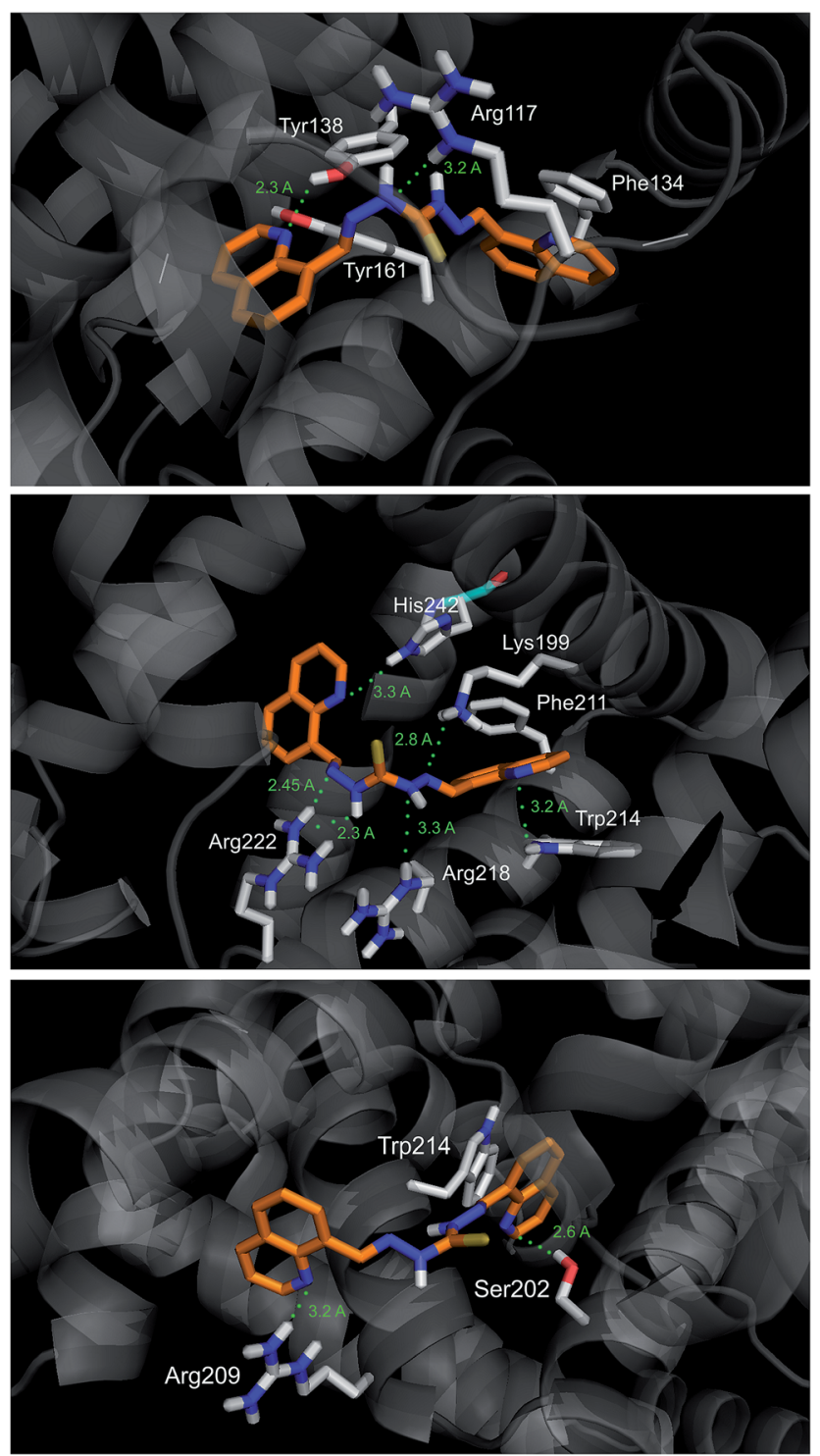

Fig. 9 S2 (orange) docked into the site IB (top), IIA (middle), and IIIA (bottom) of HSA. Amino acid residues, which interact with the S2 are shown as sticks and colored by atom. The most important polar interactions are highlighted as green dots, together with corresponding distances. (at distance $3.3 \AA$ ) , Arg222 (2.3-2.45 ̊), Lys199 (2.8 А) as well as Trp214 (3.2 А). Hydrophobic and/or $\pi-\pi$ stacking interactions between AB39 and Phe211 and Trp214 are also possible. Lesser number of polar interactions are observed for AB39 binding into the sites IB and IIIA.

Binding mode of S2 into the site IIA of HSA confirms the dominant contribution of hydrogen bonding in overall binding energy.

\section{Conclusion}

Results of the current study validate superior anti-cancer activity of TCHs over CHs. Used set of biological tests provides preliminary information on mechanism of their activity. Particularly attractive is their ability to target different phases of mitotic division in concentration-dependent manner, which for some compounds was overlapping with alterations in intensity of apoptotic response of treated cells. That information strongly indicate on multi-target activity profile of investigated TCHs. Furthermore, apoptosis induced by these compounds was not exclusively caspase-dependent, while activation of caspase-8 was assayed as the principal trend signifying on endoplasmic reticulum stress or even activation of death receptor signaling as the triggering incident of apoptotic death. Induction of ROS genesis in mitochondria was shown to be trivial accident since there was no obvious correlation between potency in ROS production and intensity of apoptotic response. Among tested compounds, only two bis-TCHs also revealed pro-apoptotic activity on CSCs, while two bis-CHs induced necrotic death on this cell model. However, investigation on 3D spheroidal CSC model that is a superior platform for testing the drug activity compared to standardly used 2D monolayer, gave more accurate perspective on antitumor activity of evaluated drugs. According to those data, compound $\mathbf{S 6}$ as the only TCH that revealed strong pro-apoptotic activity on AsPC-1 2D model, showed on spheroids a sustained antitumor activity with significantly reduced size of treated spheres compared to their initial volume. Moreover, compound S6 drastically reduced percentage of CD44 positive CSCs over the 3 day incubation time, and therefore displayed its ability to act also as a pro-differentiation agent at low concentrations levels. Those results strongly encourage additional study of mono- and bis-TCHs, with mechanism of caspase- 8 activation as the primary interest in any further investigations.

\section{Experimental}

\section{Reagents and instrumentation}

2-Quinolinecarboxaldehyde $\quad(\geq 98 \%), \quad$ thiocarbohydrazide (98\%) and carbohydrazide ( $\geq 98 \%$ ) were obtained from Sigma. 8-Quinolinecarboxaldehyde (98\%) and 8-hydroxy-2quinolinecarboxaldehyde (98\%) were obtained from Acros Organics. All solvents (reagent grade) were obtained from commercial suppliers and used without further purification.

Elemental analyses (C, H, N, S) were performed by the standard micromethods using the ELEMENTAR Vario EL III CHNS/O analyzer. Fourier-transform infrared (FTIR) spectra were obtained using FTIR BOMEM MB 100 in the form of 
$\mathrm{KBr}$ pellets. FTIR spectra (Fig. S5 and S6, ESI $\dagger$ ) were recorded in the transmission mode between 400 and $4000 \mathrm{~cm}^{-1}$ with a resolution of $4 \mathrm{~cm}^{-1}$. Abbreviations used for IR spectra: vs, very strong; s, strong; m, medium; w, weak. All NMR spectral measurements were performed on a Bruker Avance III 500 spectrometer equipped with a broad-band direct probe. The spectra were recorded at room temperature in DMSO- $d_{6}$. Chemical shifts are given on $\delta$ scale relative to tetramethylsilane (TMS), as internal standard for ${ }^{1} \mathrm{H}$ and ${ }^{13} \mathrm{C}$. Coupling constants $(J)$ were expressed in $\mathrm{Hz}$. Abbreviations used for NMR spectra: s, singlet; dd, doublet of doublets; ddd, double double doublet. 1D $\left({ }^{1} \mathrm{H}\right.$ and ${ }^{13} \mathrm{C}$ ) and $2 \mathrm{D}$ (COSY, NOESY, ${ }^{1} \mathrm{H}_{-}{ }^{13} \mathrm{C}$ HSQC and ${ }^{1} \mathrm{H}_{-}{ }^{13} \mathrm{C} \mathrm{HMBC}$ ) spectra of all compounds are shown in Fig. S8-S79 (ESI $\dagger$ ) together with the atom numbering scheme (Table S1, ESI $\dagger$ ).

\section{Synthesis of compounds}

General procedure for the preparation of mono (thio)carbohydrazones 01, O3, O5, S1, S3, S5

Example: 8-quinolinealdehyde carbohydrazone (O1). Solution of 8-quinolinecarboxaldehyde $(0.0785 \mathrm{~g}, 0.5 \mathrm{mmol})$ in ethanol $(10 \mathrm{~mL})$ was added into hot solution of $\mathrm{dhO}(0.0901 \mathrm{~g}, 1 \mathrm{mmol})$ in ethanol $(40 \mathrm{~mL})$. After the catalytic amount of conc. hydrochloric acid was added, reaction mixture was stirred and refluxed for $3 \mathrm{~h}$. The resulting precipitate was collected by filtration and washed successively with cold ethanol and diethyl ether. Yellow solid was recrystallized from absolute methanol. Yield: $0.0733 \mathrm{~g}$ (64\%). Mp $185{ }^{\circ} \mathrm{C}$. Elemental analysis calcd for $\mathrm{C}_{11} \mathrm{H}_{11} \mathrm{~N}_{5} \mathrm{O}\left(M_{\mathrm{w}}=229.24 \mathrm{~g} \mathrm{~mol}^{-1}\right)$ : $\mathrm{C}, 57.63 ; \mathrm{H}$, 4.84; N, 30.55\%; found: C, 57.71; H, 4.78; N, 30.62\%. IR ( KBr, $\left.\mathrm{cm}^{-1}\right) \nu_{\text {max }}: 3316 \mathrm{~s}\left(\mathrm{NH}_{2}\right), 3200 \mathrm{~s}(\mathrm{NH}), 3096 \mathrm{~m}\left(\mathrm{CH}_{\text {aryl }}\right), 1681 \mathrm{vs}$ $(\mathrm{C}=\mathrm{O}), 1621 \mathrm{~m}(\mathrm{C}=\mathrm{N}) ;{ }^{1} \mathrm{H}$ NMR $\left(500.26 \mathrm{MHz}, \mathrm{DMSO}-d_{6}\right)$ $\delta$ (ppm): 4.12 (s, 2H, H-N5), 7.57 (dd, $1 \mathrm{H}, \mathrm{H}-\mathrm{C} 3,{ }^{3} J_{3,4}=8.3 \mathrm{~Hz}$, ${ }^{3} J_{3,2}=4.1 \mathrm{~Hz}$ ), $7.63\left(\mathrm{t}, 1 \mathrm{H}, \mathrm{H}-\mathrm{C} 6,{ }^{3} J_{6,5}={ }^{3} J_{6,7}=7.4 \mathrm{~Hz}\right), 7.98(\mathrm{dd}$, $\left.1 \mathrm{H}, \mathrm{H}-\mathrm{C} 5,{ }^{3} J_{5,6}=7.8 \mathrm{~Hz},{ }^{4} J_{5,7}=1 \mathrm{~Hz}\right), 8.16(\mathrm{~s}, 1 \mathrm{H}, \mathrm{H}-\mathrm{N} 4), 8.39$ (dd, $\left.1 \mathrm{H}, \mathrm{H}-\mathrm{C} 4,{ }^{3} J_{4,3}=8.3 \mathrm{~Hz},{ }^{4} J_{4,2}=2.0 \mathrm{~Hz}\right), 8.58(\mathrm{~d}, 1 \mathrm{H}, \mathrm{H}-\mathrm{C} 7$, ${ }^{3} J_{7,6}=7.4 \mathrm{~Hz}$ ), $8.94\left(\mathrm{dd}, 1 \mathrm{H}, \mathrm{H}-\mathrm{C} 2,{ }^{3} J_{2,3}=4.1 \mathrm{~Hz},{ }^{3} J_{2,4}=2.0\right.$ $\mathrm{Hz}$ ), 9.14 (s, 1H, H-C9), 10.65 (s, 1H, H-N3). ${ }^{13} \mathrm{C}$ NMR (126.0 MHz, DMSO- $\left.d_{6}\right) \delta(\mathrm{ppm}): 121.67$ (C3), 125.61 (C7), 126.45 (C6), 127.94 (C4a), 128.90 (C5), 131.59 (C8), 136.55 (C4), 136.89 (C9), 145.01 (C8a), 150.08 (C2), 157.21 (C10).

2-Quinolinealdehyde carbohydrazone (O3). 03 was synthesized similarly to 01, starting from 2-quinolinecarboxaldehyde and dhO. White solid was recrystallized from absolute methanol. Yield: $56 \%$. Mp $183{ }^{\circ} \mathrm{C}$. Elemental analysis calcd for $\mathrm{C}_{11} \mathrm{H}_{11} \mathrm{~N}_{5} \mathrm{O}$ $\left(M_{\mathrm{w}}=229.24 \mathrm{~g} \mathrm{~mol}^{-1}\right): \mathrm{C}, 57.63 ; \mathrm{H}, 4.84 ; \mathrm{N}, 30.55 \%$, found: $\mathrm{C}$, $57.58 ; \mathrm{H}, 4.62 ; \mathrm{N}, 30.69 \%$. IR $\left(\mathrm{KBr}, \mathrm{cm}^{-1}\right) \nu_{\max }: 3297 \mathrm{~s}\left(\mathrm{NH}_{2}\right)$, 3188s (NH), 3084m ( $\left.\mathrm{CH}_{\text {aryl }}\right), 1679 \mathrm{vs}(\mathrm{C}=\mathrm{O}), 1638 \mathrm{~m}(\mathrm{C}=\mathrm{N}) \cdot{ }^{1} \mathrm{H}$ NMR (500.26 MHz, DMSO- $\left.d_{6}\right) \delta$ (ppm): 4.15 (s, 2H, H-N5), 7.58 (ddd, $1 \mathrm{H}, \mathrm{H}-\mathrm{C} 6,{ }^{3} \mathrm{~J}_{6,7}=8.2 \mathrm{~Hz}$ ), 7.74 (ddd, $1 \mathrm{H}, \mathrm{H}-\mathrm{C} 7,{ }^{3} J_{7,6}=8.2$ Hz), 7.93-7.99 (br.m.ovlp., 2H, H-C5, H-C8), 8.03 (s, 1H, H-C9), 8.27 (d, $1 \mathrm{H}, \mathrm{H}-\mathrm{C} 4,{ }^{3} J_{4,3}=8.4 \mathrm{~Hz}$ ), 8.34-8.46 (br.m.ovlp., $2 \mathrm{H}, \mathrm{H}-$ $\left.\mathrm{C} 3, \mathrm{H}-\mathrm{N} 4,{ }^{3} \mathrm{~J}_{3,4}=8.4 \mathrm{~Hz}\right), 10.84(\mathrm{~s}, 1 \mathrm{H}, \mathrm{H}-\mathrm{N} 3) .{ }^{13} \mathrm{C}$ NMR $(126.0$ MHz, DMSO- $d_{6}$ ) $\delta$ (ppm): 118.03 (C3), 126.84 (C6), 127.66 (4a), 127.92 (C5), 128.69 (C8), 129.82 (C7), 136.19 (C4), 140.64 (C9), 147.26 (C8a), 154.34 (C2), 156.76 (C10).
8-Hydroxy-2-quinolinealdehyde carbohydrazone (O5). 05 was synthesized similarly to $\mathbf{0 1}$, starting from 8-hydroxy-2quinolinecarboxaldehyde and dho. Yellow solid was recrystallized from absolute methanol. Yield: 72\%. Mp 214-215 ${ }^{\circ} \mathrm{C}$. Elemental analysis calcd for $\mathrm{C}_{11} \mathrm{H}_{11} \mathrm{~N}_{5} \mathrm{O}_{2}\left(M_{\mathrm{w}}=245.24 \mathrm{~g} \mathrm{~mol}^{-1}\right)$ : C, 53.83; H, 4.525; N, 28.56\%; found: C, 53.66; H, 4.68; N, $28.74 \%$. IR (KBr, cm $\left.{ }^{-1}\right) \nu_{\max }: 3371 \mathrm{~s}(\mathrm{OH}), 3335 \mathrm{~s}\left(\mathrm{NH}_{2}\right), 3198 \mathrm{~s}$ $(\mathrm{NH}), 3049 \mathrm{~m}\left(\mathrm{CH}_{\text {aryl }}\right), 1696 \mathrm{vs}(\mathrm{C}=\mathrm{O}), 1600 \mathrm{~m}(\mathrm{C}=\mathrm{N}) \cdot{ }^{1} \mathrm{H} \mathrm{NMR}$ (500.26 MHz, DMSO- $\left.d_{6}\right) \delta(\mathrm{ppm}): 4.14$ (s, 2H, H-N5), 7.08 (dd, $\left.1 \mathrm{H}, \mathrm{H}-\mathrm{C} 7,{ }^{4} J_{7,5}=1.4 \mathrm{~Hz}\right), 7.36\left(\mathrm{dd}, 1 \mathrm{H}, \mathrm{H}-\mathrm{C} 5,{ }^{4} J_{5,7}=1.4 \mathrm{~Hz}\right)$, 7.41 (m, 1H, H-C6), 8.09 (s, 1H, H-C9), 8.24 (d, 1H, H-C4, ${ }^{3} J_{4,3}=$ $8.55 \mathrm{~Hz}$ ), 8.30-8.50 (br.m.ovlp., $2 \mathrm{H}, \mathrm{H}-\mathrm{C} 3, \mathrm{H}-\mathrm{N} 4,{ }^{3} J_{3,4}=8.55$ $\mathrm{Hz}), 9.71$ (s, 1H, OH), 10.88 (s, 1H, H-N3). ${ }^{13} \mathrm{C} \mathrm{NMR}(126.0 \mathrm{MHz}$, DMSO- $\left.d_{6}\right) \delta(\mathrm{ppm}): 111.59$ (C7), 117.74 (C5), 118.35 (C3), 127.73 (C6), 128.52 (C4a), 136.06 (C4), 137.93 (C8a), 140.50 (C9), 152.25 (C2), 153.24 (C8), 156.83 (C10).

8-Quinolinealdehyde thiocarbohydrazone (S1). S1 was synthesized similarly to $\mathbf{0 1}$, starting from dhs instead of dhO. Yellow solid was recrystallized from water/ethanol mixture $(1: 4, \mathrm{v} / \mathrm{v})$. Yield 75\%. Mp 163-164 ${ }^{\circ} \mathrm{C}$. Elemental analysis calcd for $\mathrm{C}_{11} \mathrm{H}_{11} \mathrm{~N}_{5} \mathrm{~S}\left(M_{\mathrm{W}}=245.30 \mathrm{~g} \mathrm{~mol}^{-1}\right): \mathrm{C}, 53.86 ; \mathrm{H}, 4.52 ; \mathrm{N}, 28.55 ; \mathrm{S}$, $13.07 \%$; found: C, 53.75; H, 4.64; N, 28.40; S, $13.22 \%$. IR ( $\mathrm{KBr}$, $\left.\mathrm{cm}^{-1}\right) \nu_{\max }: 3438 \mathrm{~s}(\mathrm{NH}), 3249 \mathrm{w}\left(\mathrm{NH}_{2}\right), 2921 \mathrm{~m}\left(\mathrm{CH}_{\text {aryl }}\right), 1500 \mathrm{vs}$ (amide II); $1237 \mathrm{~m}(\mathrm{C}=\mathrm{S}) .{ }^{1} \mathrm{H}$ NMR (500.26 MHz, DMSO- $d_{6}$ ) $\delta$ (ppm): 4.91 (s, 2H, H-N5), 7.59 (dd, $1 \mathrm{H}, \mathrm{H}-\mathrm{C} 3,{ }^{3} J_{3,2}=4.15 \mathrm{~Hz}$, ${ }^{3} J_{3,4}=8.35 \mathrm{~Hz}$ ), 7.65 (t, 1H, H-C6, ${ }^{3} J_{6,5}=7.9 \mathrm{~Hz},{ }^{3} J_{6,7}=7.25 \mathrm{~Hz}$ ), 8.03 (dd, $\left.1 \mathrm{H}, \mathrm{H}-\mathrm{C} 5,{ }^{3} \mathrm{~J}_{5,6}=7.9 \mathrm{~Hz}\right), 8.41\left(\mathrm{dd}, 1 \mathrm{H}, \mathrm{H}-\mathrm{C} 4,{ }^{3} J_{4,3}=\right.$ $8.35 \mathrm{~Hz}$ ), 8.73 (d, 1H, H-C7, ${ }^{3} J_{7,6}=7.25 \mathrm{~Hz}$ ), 8.96 (dd, $1 \mathrm{H}, \mathrm{H}-\mathrm{C} 2$, ${ }^{3} J_{2,3}=4.15 \mathrm{~Hz}$ ), 9.30 (s, 1H, H-C9), 9.95 (s, 1H, H-N4), 11.67 (s, $1 \mathrm{H}, \mathrm{H}-\mathrm{N} 3) .{ }^{13} \mathrm{C}$ NMR (126.0 MHz, DMSO- $\left.d_{6}\right) \delta(\mathrm{ppm}): 121.75$ (C3), 126.33 (C7), 126.40 (C6), 127.94 (C4a), 129.59 (C5), 131.21 (C8), 136.59 (C4), 138.97 (C9), 145.30 (C8a), 150.29 (C2), 175.96 (C10).

2-Quinolinealdehyde thiocarbohydrazone (S3). S3 was synthesized similarly to $\mathbf{0 1}$, starting from 2-quinolinecarboxaldehyde and dhS. Yellow solid was recrystallized from absolute ethanol. Yield: $56 \%$. Mp $183{ }^{\circ} \mathrm{C}$. Elemental analysis, calcd for $\mathrm{C}_{11} \mathrm{H}_{11} \mathrm{~N}_{5} \mathrm{~S}$ $\left(M_{\mathrm{w}}=245.30 \mathrm{~g} \mathrm{~mol}^{-1}\right): \mathrm{C}, 53.86 ; \mathrm{H}, 4.52 ; \mathrm{N}, 28.55 ; \mathrm{S}, 13.07 \%$; found: C, 53.66; H, 4.48; N, 28.32; S, 13.17\%. IR $\left(\mathrm{KBr}, \mathrm{cm}^{-1}\right)$ $\nu_{\text {max }}: 3425 \mathrm{~m}(\mathrm{NH}), 3267 \mathrm{~s}\left(\mathrm{NH}_{2}\right), 2962 \mathrm{w}\left(\mathrm{CH}_{\text {aryl }}\right), 1500 \mathrm{vs}$ (amide $\mathrm{II}) ; 1230 \mathrm{~s}(\mathrm{C}=\mathrm{S}) .{ }^{1} \mathrm{H}$ NMR $\left(500.26 \mathrm{MHz}, \mathrm{DMSO}-d_{6}\right) \delta(\mathrm{ppm}): 4.97$ (s, 2H, H-N5), 7.59 (ddd, 1H, H-C6, ${ }^{3} J_{6,7}=8.2 \mathrm{~Hz}$ ), 7.75 (ddd, $1 \mathrm{H}, \mathrm{H}-\mathrm{C} 7,{ }^{3} J_{7,6}=8.2 \mathrm{~Hz}$ ), 7.97 (dd, 2H, H-C5, H-C8), 8.18 (s, $1 \mathrm{H}$, $\mathrm{H}-\mathrm{C} 9), 8.34$ (d, $\left.1 \mathrm{H}, \mathrm{H}-\mathrm{C} 4,{ }^{3} J_{4,3}=8.7 \mathrm{~Hz}\right), 8.52$ (d, $1 \mathrm{H}, \mathrm{H}-\mathrm{C} 3, J_{3,4}$ $=8.7 \mathrm{~Hz}), 10.18(\mathrm{~s}, 1 \mathrm{H}, \mathrm{H}-\mathrm{N} 4), 11.78(\mathrm{~s}, 1 \mathrm{H}, \mathrm{H}-\mathrm{N} 3) .{ }^{13} \mathrm{C} \mathrm{NMR}$ (126.0 MHz, DMSO- $d_{6}$ ) $\delta$ (ppm): 118.00 (C3), 126.75 (C6), 127.46 (4a), 127.57 (C5), 128.40 (C8), 129.57 (C7), 135.89 (C4), 141.98 (C9), 146.97 (C8a), 153.68 (C2), 175.37 (C10).

8-Hydroxy-2-quinolinealdehyde thiocarbonohydrazone (S5). S5 was synthesized similarly to $\mathbf{0 1}$, starting from 8-hydroxy-2quinolinecarboxaldehyde and dhs. Yellow solid was recrystallized from DMF/methanol mixture (1:9, v/v). Yield 83\%. Mp 208-209 ${ }^{\circ} \mathrm{C}$. Elemental analysis calcd for $\mathrm{C}_{11} \mathrm{H}_{11} \mathrm{~N}_{5} \mathrm{OS}\left(M_{\mathrm{w}}=\right.$ $261.30 \mathrm{~g} \mathrm{~mol}^{-1}$ ): C, 50.56; H, 4.24; N, 26.80; S, 12.27\%; found: C, $50.42 ; \mathrm{H}, 4.34 ; \mathrm{N}, 28.77 ; \mathrm{S}, 12.42 \%$. IR $\left(\mathrm{KBr}, \mathrm{cm}^{-1}\right) \nu_{\max }: 3450 \mathrm{~s}$ $(\mathrm{OH}), 3424 \mathrm{~s}(\mathrm{NH}), 3165 \mathrm{~m}(\mathrm{NH}), 3015 \mathrm{~m}\left(\mathrm{CH}_{\text {aryl }}\right), 1503 \mathrm{vs}$ (amide II); $1228 \mathrm{~s}(\mathrm{C}=\mathrm{S}) .{ }^{1} \mathrm{H}$ NMR $\left(500.26 \mathrm{MHz}, \mathrm{DMSO}-d_{6}\right) \delta(\mathrm{ppm}): 4.96$ 
(s, 2H, H-N5), 7.09 (dd, $1 \mathrm{H}, \mathrm{H}-\mathrm{C} 7,{ }^{3} J_{7,6}=7.65 \mathrm{~Hz},{ }^{4} J_{7,5}=1.1 \mathrm{~Hz}$ ), 7.37 (dd, $\left.1 \mathrm{H}, \mathrm{H}-\mathrm{C} 5,{ }^{3} J_{5,6}=7.9 \mathrm{~Hz},{ }^{4} J_{5,7}=1.1 \mathrm{~Hz}\right), 7.42(\mathrm{t}, 1 \mathrm{H}, \mathrm{H}-$ C6, $\left.{ }^{3} J_{6,5}=7.9 \mathrm{~Hz},{ }^{3} J_{6,7}=7.6 \mathrm{~Hz}\right), 8.23(\mathrm{~s}, 1 \mathrm{H}, \mathrm{H}-\mathrm{C} 9), 8.27(\mathrm{~d}, 1 \mathrm{H}$, $\left.\mathrm{H}-\mathrm{C} 4,{ }^{3} J_{4,3}=8.7 \mathrm{~Hz}\right), 8.52\left(\mathrm{~d}, 1 \mathrm{H}, \mathrm{H}-\mathrm{C} 3,{ }^{3} J_{3,4}=8.7 \mathrm{~Hz}\right), 9.80(\mathrm{~s}$, 1H, OH), 10.17 (s, 1H, H-N4), 11.84 (s, 1H, H-N3). ${ }^{13} \mathrm{C}$ NMR (126.0 MHz, DMSO- $d_{6}$ ) $\delta$ (ppm): 112.00 (C7), 117.71 (C5), 118.65 (C3), 127.97 (C6), 128.71 (C4a), 136.03 (C4), 138.10 (C8a), 142.16 (C9), 151.95 (C2), 153.36 (C8), 175.72 (C10).

General procedure for the preparation of bis-(thio)carbohydrazones O2, 04, O6, S2, S4, S6

Example: bis-(8-quinolinealdehyde) carbohydrazone (O2). Solution of 8-quinolinecarboxaldehyde $(0.33 \mathrm{~g}, 2.1 \mathrm{mmol})$ in ethanol $(10 \mathrm{~mL})$ was added into hot solution of $\mathrm{dhO}(0.0901 \mathrm{~g}, 1$ $\mathrm{mmol})$ in ethanol $(40 \mathrm{~mL})$. After the catalytic amount of conc. hydrochloric acid was added, reaction mixture was stirred and refluxed for $3 \mathrm{~h}$. The resulting precipitate was collected by filtration and washed successively with cold ethanol and diethyl ether. Yellow solid was recrystallized from absolute methanol. Yield: $0.199 \mathrm{~g}$ (54\%). Mp 219-220 ${ }^{\circ} \mathrm{C}$. Elemental analysis calcd for $\mathrm{C}_{21} \mathrm{H}_{16} \mathrm{~N}_{6} \mathrm{O}\left(M_{\mathrm{w}}=368.14 \mathrm{~g} \mathrm{~mol}^{-1}\right): \mathrm{C}, 68.47 ; \mathrm{H}, 4.38 ; \mathrm{N}$, 22.81\%; found: C, 68.32; H, 4.91; N, 22.73\%. IR $\left(\mathrm{KBr}, \mathrm{cm}^{-1}\right)$ $\nu_{\max }: 3331 \mathrm{~s}(\mathrm{NH}), 3055 \mathrm{~m}\left(\mathrm{CH}_{\text {aryl }}\right), 1707 \mathrm{vs}(\mathrm{C}=\mathrm{O}), 1614 \mathrm{w}(\mathrm{C}=\mathrm{N})$. ${ }^{1} \mathrm{H}$ NMR (500.26 MHz, DMSO- $\left.d_{6}\right) \delta(\mathrm{ppm}): 7.61$ (dd, 2H, H-C3= $\left.\mathrm{H}-\mathrm{C} 17,{ }^{3} J_{3,2}={ }^{3} J_{17,18}=4.1 \mathrm{~Hz},{ }^{3} J_{3,4}={ }^{3} J_{17,16}=8.3 \mathrm{~Hz}\right) ; 7.72(\mathrm{t}$, $\left.2 \mathrm{H}, \mathrm{H}-\mathrm{C} 6=\mathrm{H}-\mathrm{C} 14,{ }^{3} J_{6,5}={ }^{3} J_{14,15}=7.9 \mathrm{~Hz}\right) ; 8.04(\mathrm{dd}, 2 \mathrm{H}, \mathrm{H}-$ $\left.\mathrm{C} 5=\mathrm{H}-\mathrm{C} 15,{ }^{3} J_{5,6}={ }^{3} J_{15,14}=7.9 \mathrm{~Hz}\right) ; 8.43(\mathrm{dd}, 2 \mathrm{H}, \mathrm{H}-\mathrm{C} 4=\mathrm{H}-$ $\left.\mathrm{C} 16,{ }^{3} J_{4,3}={ }^{3} J_{16,17}=8.3 \mathrm{~Hz},{ }^{4} J_{4,2}={ }^{4} J_{16,18}=1.75 \mathrm{~Hz}\right) ; 8.60(\mathrm{~d}, 2 \mathrm{H}$, $\mathrm{H}-\mathrm{C} 7=\mathrm{H}-\mathrm{C} 13$ ); 8.99 (dd, $2 \mathrm{H}, \mathrm{H}-\mathrm{C} 2=\mathrm{H}-\mathrm{C} 18,{ }^{3} J_{2,3}={ }^{3} J_{18,17}=$ $\left.4.1 \mathrm{~Hz},{ }^{4} J_{2,4}={ }^{4} J_{18,16}=1.75 \mathrm{~Hz}\right) ; 9.50(\mathrm{~s}, 2 \mathrm{H}, \mathrm{H}-\mathrm{C} 9=\mathrm{H}-\mathrm{C} 11)$; 11.09 (s, 2H, H-N3, H-N4). ${ }^{13} \mathrm{C}$ NMR (126.0 MHz, DMSO- $d_{6}$ ) $\delta(\mathrm{ppm}): 121.77(\mathrm{C} 3=\mathrm{C} 17) ; 125.72(\mathrm{C} 7=\mathrm{C} 13) ; 126.49(\mathrm{C} 6=\mathrm{C} 14)$; $128.02(\mathrm{C} 4 \mathrm{a}=\mathrm{C} 15 \mathrm{a}) ; 129.28(\mathrm{C} 5=\mathrm{C} 15) ; 131.65 \quad(\mathrm{C} 8=\mathrm{C} 12)$; $136.62(\mathrm{C} 4=\mathrm{C} 16) ; 139.89 \quad(\mathrm{C} 9=\mathrm{C} 11) ; 145.19 \quad(\mathrm{C} 8 \mathrm{a}=\mathrm{C} 12 \mathrm{a})$, $150.16(\mathrm{C} 2=\mathrm{C} 18) ; 152.28$ (C10).

Bis-(2-quinolinealdehyde) carbohydrazone (O4). 04 was synthesized similarly to $\mathbf{O 2}$, starting from 2-quinolinecarboxaldehyde and dhO, with a slight modification of previously published procedure. ${ }^{47}$ White solid was recrystallized from DMF/methanol mixture (1 : 9, v/v). Yield 78\%. Mp 162-164 ${ }^{\circ} \mathrm{C}$. Elemental analysis calcd for $\mathrm{C}_{21} \mathrm{H}_{16} \mathrm{~N}_{6} \mathrm{O}\left(M_{\mathrm{w}}=368.14 \mathrm{~g} \mathrm{~mol}^{-1}\right)$ : C, 68.47; H, 4.38; N, 22.81\%; found: C, 68.81; H, 4.80; N, 22.56\%. IR $\left(\mathrm{KBr}, \mathrm{cm}^{-1}\right) \nu_{\text {max }}: 3392 \mathrm{~s}(\mathrm{NH}), 3096 \mathrm{~m}\left(\mathrm{CH}_{\text {aryl }}\right), 1708 \mathrm{vs}(\mathrm{C}=\mathrm{O})$, 1630w $(\mathrm{C}=\mathrm{N}) .{ }^{1} \mathrm{H}$ NMR (500.26 MHz, DMSO- $\left.d_{6}\right) \delta(\mathrm{ppm}): 7.63$ (ddd, 2H, H-C6 $=\mathrm{H}-\mathrm{C} 16,{ }^{3} J_{6,7}={ }^{3} J_{16,17}=6.8 \mathrm{~Hz},{ }^{3} J_{6,5}={ }^{3} J_{16,15}=$ $8.2 \mathrm{~Hz}$ ), 7.79 (ddd, $2 \mathrm{H}, \mathrm{H}-\mathrm{C} 7=\mathrm{H}-\mathrm{C} 17,{ }^{3} J_{7,6}={ }^{3} J_{17,16}=6.8 \mathrm{~Hz}$ ), 8.02 (ddd, $4 \mathrm{H}, \mathrm{H}-\mathrm{C} 5=\mathrm{H}-\mathrm{C} 15, \mathrm{H}-\mathrm{C} 8=\mathrm{H}-\mathrm{C} 18,{ }^{3} J_{5,6}={ }^{3} J_{15,16}=$ $8.2 \mathrm{~Hz}$ ), 8.31 (s, 2H, H-C9=H-C11), 8.38-8.60 (br.m.ovlp., 4H, $\mathrm{H}-\mathrm{C} 3=\mathrm{H}-\mathrm{C} 13, \mathrm{H}-\mathrm{C} 4=\mathrm{H}-\mathrm{C} 14), 11.31(\mathrm{~s}, 2 \mathrm{H}, \mathrm{H}-\mathrm{N} 3=\mathrm{H}-\mathrm{N} 4) .{ }^{13} \mathrm{C}$ NMR (126.0 MHz, DMSO- $\left.d_{6}\right) \delta(\mathrm{ppm}): 117.78$ (C3=C13), 127.11 $(\mathrm{C} 7=\mathrm{C} 17), 127.79(\mathrm{C} 6=\mathrm{C} 16), 127.99(\mathrm{C} 4 \mathrm{a}=\mathrm{C} 14 \mathrm{a}), 128.84(\mathrm{C} 5=$ C15), $130.00(\mathrm{C} 8=\mathrm{C} 18), 136.47(\mathrm{C} 4=\mathrm{C} 14), 144.06$ (C9=C11), $147.35(\mathrm{C} 8 \mathrm{a}=\mathrm{C} 18 \mathrm{a}), 151.67(\mathrm{C} 2=\mathrm{C} 12), 153.99(\mathrm{C} 10)$.

Bis-(8-hydroxy-2-quinolinealdehyde) carbohydrazone (O6). 06 was synthesized similarly to $\mathbf{O 2}$, starting from 8-hydroxy-2quinolinecarboxaldehyde and dho. Yellow solid was recrystallized from DMF/methanol mixture (1:9, v/v). Yield: 66\%. Mp 248-249 ${ }^{\circ} \mathrm{C}$. Elemental analysis calcd for $\mathrm{C}_{21} \mathrm{H}_{16} \mathrm{~N}_{6} \mathrm{O}_{3}\left(M_{\mathrm{w}}=\right.$ $\left.400.39 \mathrm{~g} \mathrm{~mol}^{-1}\right)$ : C, 62.99; H, 4.03; N, 20.99, \%; found: C, 62.84; $\mathrm{H}, 4.11$; N, 21.22\%. IR (KBr, cm ${ }^{-1}$ ) $\nu_{\text {max }}: 3408 \mathrm{~s}(\mathrm{OH}), 3230 \mathrm{~m}$ $\left(\mathrm{NH}_{2}\right), 3116 \mathrm{~m}(\mathrm{NH}), 2925 \mathrm{~m}\left(\mathrm{CH}_{\text {aryl }}\right), 1684 \mathrm{vs}(\mathrm{C}=\mathrm{O}), 1601 \mathrm{w}(\mathrm{C}=$ N). ${ }^{1} \mathrm{H}$ NMR (500.26 MHz, DMSO- $\left.d_{6}\right) \delta$ (ppm): 7.12 (dd, 2H, H$\left.\mathrm{C} 7=\mathrm{H}-\mathrm{C} 17,{ }^{3} J_{7,6}={ }^{3} J_{17,16}=7.4 \mathrm{~Hz},{ }^{4} J_{7,5}={ }^{4} J_{17,15}=1.5 \mathrm{~Hz}\right), 7.41$ $\left(\mathrm{dd}, 2 \mathrm{H}, \mathrm{H}-\mathrm{C} 5=\mathrm{H}-\mathrm{C} 15,{ }^{4} J_{5,7}={ }^{4} J_{15,17}=1.5 \mathrm{~Hz}\right), 7.45(\mathrm{t}, 2 \mathrm{H}, \mathrm{H}-$ $\mathrm{C} 6=\mathrm{H}-\mathrm{C} 16,{ }^{3} \mathrm{~J}_{6,7}={ }^{3} J_{16,17}=7.4 \mathrm{~Hz}$ ), 8.17-8.39 (br.m.ovlp., $4 \mathrm{H}$, $\mathrm{H}-\mathrm{C} 3=\mathrm{H}-\mathrm{C} 13, \mathrm{H}-\mathrm{C} 4=\mathrm{H}-\mathrm{C} 14), 8.48(\mathrm{~s}, 2 \mathrm{H}, \mathrm{H}-\mathrm{C} 9=\mathrm{H}-\mathrm{C} 11)$, $9.80(\mathrm{~s}, 2 \mathrm{H}, \mathrm{H}-\mathrm{O} 1=\mathrm{H}-\mathrm{O} 2), 11.34(\mathrm{~s}, 2 \mathrm{H}, \mathrm{H}-\mathrm{N} 3=\mathrm{H}-\mathrm{N} 4) .{ }^{13} \mathrm{C}$ NMR (126.0 MHz, DMSO- $\left.d_{6}\right) \delta(\mathrm{ppm}): 112.13$ (C7=C17), 117.90 $(\mathrm{C} 5=\mathrm{C} 15), 118.12(\mathrm{C} 3=\mathrm{C} 13), 128.13(\mathrm{C} 6=\mathrm{C} 16), 128.75(\mathrm{C} 4 \mathrm{a}=$ C14a), 136.40 (C4=C14), $138.13(\mathrm{C} 8 \mathrm{a}=\mathrm{C} 18 \mathrm{a}), 144.02$ (C9= C11), 151.92 (C2=C12), 153.37 (C8=C18), 162.45 (C10).

Bis-(8-quinolinealdehyde) thiocarbohydrazone (S2). S2 was synthesized similarly to $\mathbf{O 2}$, starting from dhS instead of dhO. Yellow solid was recrystallized from DMF/ethanol mixture $(1: 4$, $\mathrm{v} / \mathrm{v}$ ). Yield 75\%. Mp 192-193 ${ }^{\circ} \mathrm{C}$ (decomp.). Elemental analysis calcd for $\mathrm{C}_{21} \mathrm{H}_{16} \mathrm{~N}_{6} \mathrm{~S}\left(M_{\mathrm{w}}=384.12 \mathrm{~g} \mathrm{~mol}^{-1}\right): \mathrm{C}, 65.61 ; \mathrm{H}, 4.19 ; \mathrm{N}$, 21.86; S, 8.34\%; found: C, 65.44; H, 4.03; N, 21.77; S, 8.21\%. IR $\left(\mathrm{KBr}, \mathrm{cm}^{-1}\right) \nu_{\text {max }}: 3441 \mathrm{~m}(\mathrm{NH}), 3119 \mathrm{w}\left(\mathrm{CH}_{\text {aryl }}\right), 1519 \mathrm{vs}$ (amide II); $1231 \mathrm{~s}(\mathrm{C}=\mathrm{S}) .{ }^{1} \mathrm{H}$ NMR (500.26 MHz, DMSO- $\left.d_{6}\right) \delta$ (ppm): 7.62 $\left(\mathrm{dd}, 2 \mathrm{H}, \mathrm{H}-\mathrm{C} 3=\mathrm{H}-\mathrm{C} 17,{ }^{3} J_{3,4}={ }^{3} J_{17,18}=4.1 \mathrm{~Hz}\right), 7.75(\mathrm{t}, 2 \mathrm{H}, \mathrm{H}-$ $\left.\mathrm{C} 6=\mathrm{H}-\mathrm{C} 14,{ }^{3} J_{6,5}={ }^{3} J_{14,15}=7.95 \mathrm{~Hz}\right), 8.09(\mathrm{dd}, 2 \mathrm{H}, \mathrm{H}-\mathrm{C} 5=\mathrm{H}-$ $\mathrm{C} 15,{ }^{3} J_{5,6}={ }^{3} J_{15,14}=7.95 \mathrm{~Hz}$ ), 8.35-8.64 (br.m.ovrl. 3H, H-C4= $\mathrm{H}-16, \mathrm{H}-\mathrm{C} 13$ ), 8.88 (s, H-C7), 9.00 (dd, 2H, H-C2 $=\mathrm{H}-\mathrm{C} 18,{ }^{3} J_{2,3}$ $={ }^{3} J_{18,17}=4.1 \mathrm{~Hz}$ ), 9.48 (s, 1H, H-C11), 9.91 (s, 1H, H-C9), 12.14 $(\mathrm{d}, 2 \mathrm{H}, \mathrm{H}-\mathrm{N} 3=\mathrm{H}-\mathrm{N} 4) .{ }^{13} \mathrm{C} \mathrm{NMR}\left(126.0 \mathrm{MHz}, \mathrm{DMSO}-d_{6}\right) \delta(\mathrm{ppm})$ : 121.85 (C3=C17), 125.98 (C13), 126.48 (C6=C14), 126.70 (C7), $128.01(\mathrm{C} 4 \mathrm{a}=\mathrm{C} 15 \mathrm{a}), 129.99(\mathrm{C} 5=\mathrm{C} 15), 130.97$ (C12), 131.46 (C8), $136.65(\mathrm{C} 4=\mathrm{C} 16), 140.36(\mathrm{C} 8 \mathrm{a}=\mathrm{C} 12 \mathrm{a}), 140.48$ (C11), 145.40 (C9), 150.34 (C2=C18), 175.21 (C10).

Bis-(2-quinolinealdehyde) thiocarbohydrazone (S4). S4 was synthesized similarly to $\mathbf{O} 2$, starting from 2-quinolinecarboxaldehyde and dhs, with a slight modification of previously published procedure. ${ }^{47}$ Yellow solid was recrystallized from DMSO/methanol mixture (9:1, v/v). Yield 68\%. Mp $184{ }^{\circ} \mathrm{C}$. Elemental analysis calcd for $\mathrm{C}_{21} \mathrm{H}_{16} \mathrm{~N}_{6} \mathrm{~S}\left(M_{\mathrm{w}}=384.12 \mathrm{~g} \mathrm{~mol}^{-1}\right)$ : C, 65.61; H, 4.19; N, 21.86; S, 8.34\%; found: C, 65.78; H, 4.01; N, 21.56; S, 8.12\%. IR (KBr, cm $\left.\left.{ }^{-1}\right) \nu_{\text {max }}: 3424 \mathrm{~s} \mathrm{(NH),} \mathrm{2923m} \mathrm{(} \mathrm{CH}_{\text {aryl }}\right)$, 1488vs (amide II); $1229 \mathrm{~s}(\mathrm{C}=\mathrm{S}) .{ }^{1} \mathrm{H}$ NMR (500.26 MHz, DMSO$\left.d_{6}\right) \delta(\mathrm{ppm}): 7.67\left(\mathrm{ddd}, 2 \mathrm{H}, \mathrm{H}-\mathrm{C} 6=\mathrm{H}-\mathrm{C} 16,{ }^{3} J_{6,7}={ }^{3} J_{16,17}=\right.$ $\left.7.05 \mathrm{~Hz},{ }^{3} J_{6,5}={ }^{3} J_{16,15}=7.95 \mathrm{~Hz}\right), 7.82(\mathrm{ddd}, 2 \mathrm{H}, \mathrm{H}-\mathrm{C} 7=\mathrm{H}-\mathrm{C} 17$, ${ }^{3} J_{7,6}={ }^{3} J_{17,16}=7.05 \mathrm{~Hz}$ ), 8.06 (ddd, $4 \mathrm{H}, \mathrm{H}-\mathrm{C} 5=\mathrm{H}-\mathrm{C} 15, \mathrm{H}-\mathrm{C} 8=$ $\left.\mathrm{H}-\mathrm{C} 18,{ }^{3} J_{5,6}={ }^{3} J_{15,16}=7.95 \mathrm{~Hz}\right), 8.20(\mathrm{~s}, 1 \mathrm{H}, \mathrm{H}-\mathrm{C} 11), 8.40(\mathrm{~s}, 1 \mathrm{H}$, $\mathrm{H}-\mathrm{C} 9$ ), 8.46-8.63 (br.m.ovlp., $4 \mathrm{H}, \mathrm{H}-\mathrm{C} 3=\mathrm{H}-\mathrm{C} 13, \mathrm{H}-\mathrm{C} 4=\mathrm{H}-$ C14), 12.16 (s, 1H, H-N4), 12.51 (s, 1H, H-N3). ${ }^{13} \mathrm{C}$ NMR (126.0 MHz, DMSO- $\left.d_{6}\right) \delta(\mathrm{ppm}): 118.41$ (C13), 118.72 (C3), 127.75 (C6= $\mathrm{C} 16), 128.23(\mathrm{C} 4 \mathrm{a}=\mathrm{C} 14 \mathrm{a}), 127.37(\mathrm{C} 5=\mathrm{C} 15), 130.47(\mathrm{C} 7=\mathrm{C} 17)$, 130.47 (C8=C18), 136.98 (C4=C14), 144.46 (C11), 149.59 (C9), $147.70(\mathrm{C} 8 \mathrm{a}=\mathrm{C} 18 \mathrm{a}), 152.03$ (C12), 153.96 (C2), 175.97 (C10).

Bis-(8-hydroxy-2-quinolinealdehyde) thiocarbohydrazone (S6). S6 was synthesized similarly to $\mathbf{0 2}$, starting from 8-hydroxy-2quinolinecarboxaldehyde and dhs. Yellow solid was recrystallized from DMF/methanol mixture (1:9, v/v). Yield 74\%; mp 240-241 ${ }^{\circ} \mathrm{C}$. Elemental analysis calcd for $\mathrm{C}_{21} \mathrm{H}_{16} \mathrm{~N}_{6} \mathrm{O}_{2} \mathrm{~S}\left(M_{\mathrm{w}}=\right.$ $416.46 \mathrm{~g} \mathrm{~mol}^{-1}$ ): C, 60.56; H, 3.87; N, 20.18; S, 7.70\%; found: C, $60.68 ; \mathrm{H}, 4.03 ; \mathrm{N}, 20.07 ; \mathrm{S}, 7.52 \%$. IR (KBr, $\left.\mathrm{cm}^{-1}\right) \nu_{\max }: 3479 \mathrm{~s}$ 
(OH), 3428m (NH), 2923m ( $\left.\mathrm{CH}_{\text {aryl }}\right), 1500 \mathrm{vs}$ (amide II); 1231s $(\mathrm{C}=\mathrm{S}) ;{ }^{1} \mathrm{H}$ NMR $\left(500.26 \mathrm{MHz}, \mathrm{DMSO}-d_{6}\right) \delta(\mathrm{ppm}): 7.14(\mathrm{~d}, 2 \mathrm{H}$, $\left.\mathrm{H}-\mathrm{C} 7=\mathrm{H}-\mathrm{C} 17,{ }^{3} \mathrm{~J}_{7,6}={ }^{3} J_{17,16}=7.4 \mathrm{~Hz}\right), 7.43(\mathrm{~m}, 4 \mathrm{H}, \mathrm{H}-\mathrm{C} 5=\mathrm{H}-$ $\mathrm{C} 15, \mathrm{H}-6=\mathrm{H}-16$ ), 8.05-8.41 (br.m.ovlp., $4 \mathrm{H}, \mathrm{H}-\mathrm{C} 3=\mathrm{H}-\mathrm{C} 13, \mathrm{H}-$ $\mathrm{C} 4=\mathrm{H}-\mathrm{C} 14), 8.53$ (s, 1H, H-C11), 8.89 (s, 1H, H-C9), 9.89 (s, 2H, $\mathrm{O} 1 \mathrm{H}=\mathrm{O} 2 \mathrm{H}), 12.18$ (s, 1H, H-N4), 12.52 (s, 1H, H-N3). ${ }^{13} \mathrm{C}$ NMR (126.0 MHz, DMSO- $\left.d_{6}\right) \delta(\mathrm{ppm}): 112.24(\mathrm{C} 7=\mathrm{C} 17), 117.87$ (C5= C15), 118.62 (C3=C13), $128.38(\mathrm{C} 6=\mathrm{C} 16), 128.90(\mathrm{C} 4 \mathrm{a}=\mathrm{C} 14 \mathrm{a})$, $136.48(\mathrm{C} 4=\mathrm{C} 14), 138.20(\mathrm{C} 8 \mathrm{a}=\mathrm{C} 18 \mathrm{a}), 143.85$ (C11), 149.17 (C9), $151.60(\mathrm{C} 2=\mathrm{C} 12), 153.44(\mathrm{C} 8=\mathrm{C} 18), 175.61(\mathrm{C} 10)$.

\section{DFT theoretical calculations, NMR and lipophilicity predictions}

Initial conformations of compounds 01-06 and S1-S6 were generated in OMEGA 2.4.3, ${ }^{90}$ using MMFF94s force field. ${ }^{92}$ The structures were additionally optimized using $\omega$ B97X-D functional, ${ }^{93}$ and $6-311 \mathrm{G}(\mathrm{d}, \mathrm{p})$ basis set. The solvation effect was simulated with polarized continuum model (PCM), ${ }^{94}$ of acetonitrile. In order to confirm that the obtained geometry represents the global minimum, vibrational frequency analysis was performed afterward (Opt + Freq keywords). No imaginary frequencies were found, so stationary point reached do represent global minimum. Different tautomeric forms and geometric isomers around azomethine $(\mathrm{C}=\mathrm{N})$ bond(s) were modeled, and the lowest energy form of each compound was (thio)keto, with $E$ configuration on every $\mathrm{C}=\mathrm{N}$ bond. Starting from global minimum found, NMR chemical shifts are calculated on $\omega$ B97X-D/6-311G(d,p) level using GIAO approximation, ${ }^{95}$ applying PCM model of DMSO. Chemical shifts are scaled to ${ }^{1} \mathrm{H}$ and ${ }^{13} \mathrm{C}$ chemical shifts of TMS. Lipophilicity of compounds was predicted starting from DFT-optimized geometries, calculating virtual $\log P$ derived from molecular lipophilicity potential. ${ }^{96}$

\section{Free radical scavenging antioxidant assay}

The proton donating ability was assayed using a protocol for the determination of radical scavenging activity. ${ }^{50}$ Compounds were dissolved in DMSO and were diluted into ten different concentrations. Commercially available DPPH radical was dissolved in methanol at a concentration of $6.58 \times 10^{-5} \mathrm{M}$. Into a 96-well microplate, $140 \mu \mathrm{L}$ of DPPH solution was loaded and $10 \mu \mathrm{L}$ DMSO solution of the tested compounds was added, or pure DMSO $(10 \mu \mathrm{L})$ as the control. The microplate was incubated for $30 \mathrm{~min}$ at $298 \mathrm{~K}$ in the dark and the absorbance was measured at $517 \mathrm{~nm}$ using a Thermo Scientific Appliskan. All the measurements were carried out in triplicate. The scavenging activity of the compounds was calculated using the eqn (4):

$$
\text { Scavenging activity }(\%)=\frac{\left(A_{\text {control }}-A_{\text {sample }}\right)}{A_{\text {control }}} \times 100
$$

where $A_{\text {sample }}$ and $A_{\text {control }}$ refer to the absorbances at $517 \mathrm{~nm}$ of $\mathrm{DPPH}$ in the sample and control solutions, respectively. $\mathrm{IC}_{50}$ values were calculated from the plotted graph of scavenging activity against the concentrations of the samples. $\mathrm{IC}_{50}$ is defined as the total antioxidant concentration necessary to decrease the amount of the initial DPPH radical by $50 \% . \mathrm{IC}_{50}$ was calculated for all compounds based on the percentage of DPPH radicals scavenged. Ascorbic acid was used as the reference compound (positive control) with concentrations 50 to $500 \mathrm{mg} \mathrm{mL}^{-1}$.

\section{Cell cultures}

The two ATCC cell lines were all purchased from LGC Standards (Molsheim, France). Human pancreatic adenocarcinoma (AsPC1, ATCC® CRL-1682) cell line was maintained in DMEM high glucose medium (Dominique Dutscher, 67172 Brumath cedex, France, Cat. no. L0102-500), while human acute monocytic leukemia cell line (THP-1, ATCC® TIB-202) was maintained in RPMI-1640 (Life Technologies, Paisley, UK, Cat. no. 11875-093), supplemented with $10 \%(\mathrm{v} / \mathrm{v})$ heat inactivated fetal bovine serum (FBS, Life Technologies, Paisley, UK, Cat. no. 10270-106) and $1 \%(\mathrm{v} / \mathrm{v})$ penicillin-streptomycin $(10000$ units per $\mathrm{mL}$ and $10000 \mu \mathrm{g} \mathrm{mL}{ }^{-1}$, Life Technologies, Paisley, UK, Cat. no. 15140122). Cells were kept at $37{ }^{\circ} \mathrm{C}$ in humidified atmosphere containing $5 \%(\mathrm{v} / \mathrm{v}) \mathrm{CO}_{2}$ during their exponential growing phase and in the course of incubation with investigated compounds.

Investigated compounds were initially dissolved in DMSO to the stock concentration of $20 \mathrm{mM}$. Further dilutions to the experimental concentrations applied on the cells have been done with RPMI-1640 or DMEM media immediately before each experiment, thus the final concentration of DMSO on cells treated with the highest applied concentration of investigated compound was $0.5 \%(\mathrm{v} / \mathrm{v})$.

\section{Annexin V and PI staining}

Cells were seeded in 96 flat bottom well plates (Corning® Costar ${ }^{\circledR}$, Cat. no. CLS3596) in a volume $0.1 \mathrm{~mL}$, at a density of 10000 per well. AsPC-1 cells were left overnight to settle, while treatment of THP- 1 cells started $2 \mathrm{~h}$ after seeding. Investigated compounds were added in a range of six concentrations. As controls, non-treated cells, cells treated with 0.5\% DMSO, and cells treated with celastrol (Enzo Life Sciences, Cat. no. ALX-350332-M025) at $50 \mu \mathrm{M}$ concentration were used.

After $24 \mathrm{~h}$ of treatment, supernatant medium with nonadherent cells were removed from plate with AsPC-1 cells and placed into another 96 well plate. Fresh PBS was added to remaining adherent cells afterwards the plate was centrifuged at $450 \mathrm{~g}$ for $10 \mathrm{~min}$. Supernatant was discarded and $200 \mu \mathrm{L}$ of trypsin-EDTA (BioWest, Nuaille, France, Cat. no. L0930-100) was added to each well. Cells were detached in about 15 minutes of incubation at $37^{\circ} \mathrm{C}$. Trypsin-EDTA was removed after additional spinning cycle, afterwards previously removed supernatant with non-adherent cells were added to trypsinized cells and stained with Annexin V-FITC (Immuno Tools, Friesoythe, Germany, Cat. no. 31490013) and PI (Miltenyl Biotec Inc, Auburn, USA, Cat. no. 130-093-233) in a volumes of $3 \mu \mathrm{L}$. In the case of THP-1 cells, Annexin V-FITC and PI were added to the wells with cells right after the incubation time was over.

Plates were analyzed on Guava ${ }^{\circledR}$ easyCyte $12 \mathrm{HT}$ Benchtop flow microcapillary cytometer (Millipore, Merck, Darmstadt, Germany) using the dedicated InCyte ${ }^{\circledR}$ software package. Cells were classified according to Annexin V-FITC (green fluorescence) and 
PI (red fluorescence) labeling on viable (double negative), preapoptotic cells (Annexin V-FITC single-stained cells), necrotic cells (PI single-stained cells), and cells in advanced phases of apoptosis (double-stained cells). Described trypsinization protocol was applied each time AsPC-1 cells were prepared for flow cytometry analyses, unless is stated otherwise.

\section{Calculation of $\mathrm{ED}_{50}$ concentration}

Percentages of Annexin V single-stained and double-stained cells were summarized for each concentration of investigated compound. The computed percentages were plotted against corresponding concentrations on a concentration-response graph. $\mathrm{ED}_{50}$ concentration was calculated as the one that corresponds to half-way of the sigmoidal concentrationdependent curve using asymmetric five-parameter logistic equation (GraphPad Prism 6 software).

\section{Cell cycle analysis}

Distribution of cells within phases of mitotic division has been evaluated on remaining cells after Annexin V/PI analysis, which right after the read out was finished were fixed in ethanol overnight at $4{ }^{\circ} \mathrm{C}$. Before reading, plates were centrifuged on $450 \mathrm{~g}$ for $10 \mathrm{~min}$, ethanol was discarded and PBS added in a volume of 100 $\mu \mathrm{L}$ per well. Cells were stained with $50 \mu \mathrm{L}$ of FxCycle ${ }^{\mathrm{TM}} \mathrm{PI} / \mathrm{RNAse}$ staining solution (Molecular Probes, Cat. no. F10797), and incubated at $37{ }^{\circ} \mathrm{C}$ for $30 \mathrm{~min}$. Plates were analysed on Guava ${ }^{\circledR}$ easyCyte $12 \mathrm{HT}$ Benchtop flow microcapillary cytometer using the dedicated InCyte ${ }^{\circledR}$ software package.

\section{Inhibition of caspase activity}

Cells were treated with investigated compound at $\mathrm{ED}_{50}$ concentration for $6 \mathrm{~h}$ with or without pan-caspase inhibitor Z-VAD-fmk (Promega, Madison, USA, Cat. no. G7232). Z-VAD-fmk was added in a concentration that was previously tested and confirmed as non-toxic to cells over $6 \mathrm{~h}$ incubation $(10 \mu \mathrm{M}$ and $20 \mu \mathrm{M}$ for THP1 and AsPC-1 cell line, respectively). As controls, non-treated cells, cells treated with Z-VAD-fmk only, and cells treated with $\mathrm{ED}_{50}$ concentration only were used. After incubation period was ended, treated cells were carried out for Annexin V/PI staining as described above, and analyzed on Guava ${ }^{\circledR}$ easyCyte 12HT Benchtop flow microcapillary cytometer using the dedicated InCyte ${ }^{\circledR}$ software package. The percent of apoptosis inhibited by Z-VAD-fmk co-treatment was determined using eqn (5):

$$
\text { Apoptosis inhibition }(\%)=\left[1-\left(\frac{\% \text { apoptosis in } \mathrm{A}}{\% \text { apoptosis in } \mathrm{B}}\right)\right] \times 100
$$

where $\mathrm{A}$ is the sample treated with $\mathrm{Z}-\mathrm{VAD}$-fmk and investigated compound at its $\mathrm{ED}_{50}$ concentration, while $\mathrm{B}$ is the corresponding sample treated only with the same investigated compound at $\mathrm{ED}_{50}$ concentration.

\section{Caspase- 8 and caspase- 9 activities}

Cells were treated with investigated compound at $\mathrm{ED}_{50}$ concentration for $6 \mathrm{~h}$ afterwards activity of caspase-8 and -9 were assayed by means of Guava Caspase 9 SR and Caspase 8 FAM kit (EMD Millipore, Cat. no. 4500-0640), following manufacturer's instructions. Cells were analysed on Guava ${ }^{\circledR}$ easyCyte 12HT Benchtop flow microcapillary cytometer using the dedicated InCyte ${ }^{\circledR}$ software package. In acquired data cells were discriminated according to expression of caspase-8 (Grn-B fluorescence), caspase-9 (Yel-B fluorescence), and 7-AAD (Red-B fluorescence).

\section{Generation of radical oxygen species in mitochondria}

Cells were treated over $6 \mathrm{~h}$ with investigated compounds in a concentration of $50 \mu \mathrm{M}$, afterwards were stained with MitoSox Red (Molecular Probes, Cat. no. M36008) according to manufacturer's recommendations. Analysis was performed on Guava ${ }^{\circledR}$ easyCyte $12 \mathrm{HT}$ Benchtop flow microcapillary cytometer using the dedicated InCyte ${ }$ software package.

\section{Investigation of pro-differentiation activity}

AsPC- 1 cells were seeded in a volume $0.1 \mathrm{~mL}$, at density 5000 per well of 96 well flat bottom plates. After $24 \mathrm{~h}$, investigated compounds were added in a volume of $0.2 \mathrm{~mL}$ to the final concentrations of 1 and $10 \mu \mathrm{M}$ per well. Wells with control cells were supplemented with medium up to the volume of $0.3 \mathrm{~mL}$. All cells, treated and non-treated controls, were incubated for another $72 \mathrm{~h}$, afterwards evaluation of changes in expression of cell surface marker of differentiation has been performed. When incubation was ended, cells were trypsinized as described above. Anti-CD44-FITC antibody (Miltenyi Biotec, Cat. no. 130-095-195) was added in a volume of $1 \mu \mathrm{M}$ to each well. Nontreated controls were labeled with anti-CD44-FITC or antiIgG-FITC (Miltenyl Biotec, Cat. no. 130-093-192). Plate was incubated at $37{ }^{\circ} \mathrm{C}$ for $30 \mathrm{~min}$, when additional spinning cycle (450 $\mathrm{g}$ for $10 \mathrm{~min}$ ) with PBS removal was performed to remove the excess of antibodies. Finally, fresh PBS was added to the wells and cells were analyzed on Guava® easyCyte $12 \mathrm{HT}$ Benchtop flow microcapillary cytometer using the dedicated InCyte ${ }^{\circledR}$ software package.

\section{Growth inhibition of 3D tumor models}

Three-dimensional AsPC-1 tumor models were made in 96 well plates (Corning, Sigma-Aldrich, St. Louis, Mo, USA, Cat. no. 4515). Tumors were left to grow for additional four days, afterwards investigated compounds were added in concentrations of 100, 10 and $1 \mu \mathrm{M}$. Evaluation has been maintained during 8 day incubation period, with media exchanged on the day 4 . Changes in the tumors sizes have been assessed on Celigo ${ }^{\circledR}$ imaging cytometer (Cyntellect, Brooks Life Science Systems, Poway, CA, USA) using Celigo software. Growth rates of nontreated and treated spheroids were computed for each day during 8 day incubation by dividing the area on the day- $n$ with the area on the day 0 .

\section{HSA binding experiments}

Fatty acid free HSA $\left(<0.007 \%\right.$ fatty acids, $\left.M_{\mathrm{w}}=66478 \mathrm{Da}\right)$ was purchased from Sigma, as well as potassium dihydrogen 
phosphate, disodium hydrogen phosphate, sodium chloride and potassium chloride used for PBS preparation. Stock solution of HSA $\left(c=1.91 \times 10^{-4} \mathrm{M}\right)$ was prepared by dissolving accurate weighted mass of commercially available lyophilized HSA in freshly prepared $1 \times$ PBS ( $\mathrm{pH} 7.36)$, and stock solution was kept in freezer in $100 \mu \mathrm{L}$ portions. The stock solution of $\mathbf{S 2}$ $\left(c=6.87 \times 10^{-4} \mathrm{M}\right)$ was prepared by dissolving proper amount of substance in DMSO, because of its low solubility in buffer. For HSA-S2 interaction studies, HSA solution was freshly prepared from the stock by dilution with a buffer (HSA concentration was kept constant, $c=7 \times 10^{-7} \mathrm{M}$ ), and titrated with $\mathbf{S 2}$ stock solution to avoid large sample dilution. Substance was added in 0.5, 1, 2, 3, 4, 5, 7 and 9 molar equivalents. After each aliquot addition, system was stirred and left to equilibrate for 15 min before UV-Vis absorption and fluorescence emission spectra recording. After addition of nine equivalents of substance, final volume of DMSO did not exceeded $2 \%(\mathrm{v} / \mathrm{v})$. It was shown that addition of $15 \%$ of DMSO did not induce structural changes in BSA, protein structurally similar to HSA. Therefore, it is unlikely that the conformation of HSA will be changed with the level of DMSO used in this study. ${ }^{97}$ Milipore water was used in the preparation of buffer solution.

Fluorescence measurements were performed on spectrofluorometer Fluoromax-4 Jobin Yvon (Horiba Scientific, Japan), equipped with Peltier element for temperature control and magnetic stirrer for cuvette, using quartz cell with $1 \mathrm{~cm}$ path length and $4 \mathrm{~mL}$ volume. Before recording of fluorescence spectrum, diluted HSA solution was ultrafiltrated using filters with $0.23 \mu \mathrm{m}$ pore size. An excitation wavelength was $280 \mathrm{~nm}$, with $5 \mathrm{~nm}$ slits; emission spectra were recorded in $300-450 \mathrm{~nm}$ wavelength range, with $5 \mathrm{~nm}$ slits, and $0.1 \mathrm{~s}$ integration time. Background PBS signal was subtracted from each spectrum.

UV-Vis spectra were recorded on a GBC Cintra6 UV/Vis spectrophotometer, using quartz cell with $1 \mathrm{~cm}$ path length and $4 \mathrm{~mL}$ volume. All spectra were recorded against the corresponding blank (PBS) in the 250-450 $\mathrm{nm}$ wavelength range at room temperature.

\section{Molecular docking studies}

For exploring the binding of $\mathbf{S} 2$ to site IB of HSA, crystal structure of HSA with idarubicin dimer (PDB code 4LB2) was used. ${ }^{98}$ For site IIA, PDB structure of indol amide derivative (PDB code 3LU7) was used. $^{99}$ For site IIIA, structure of HSA-diflunisal complex (PDB code 2BXE) was used. ${ }^{88}$ To define the receptor site, the residues in sphere of $12 \AA$ around co-crystallized ligand were used. Ligands and water molecules were removed prior to receptor preparation in AutoDock Tools 1.5.6. ${ }^{89}$ Initial conformation of S2 was generated in OMEGA 2.4.3, ${ }^{90}$ using MMFF94s force field..$^{92}$ The geometry of lowest energy conformer was further optimized using semiempirical PM6 method implemented in MOPAC 2016. ${ }^{100}$ Docking was carried in Autodock Vina 1.1.2 software. ${ }^{101}$ VEGAZZ 3.0.3 was used as a GUI. ${ }^{\mathbf{1 0 2}}$

\section{Acknowledgements}

The authors acknowledge networking support by the COST Action CM1106 StemChem - "Chemical Approaches to
Targeting Drug Resistance in Cancer Stem Cells”. The work was funded by the Ministry of Education, Science and Technological Development of the Republic of Serbia (Grants 172055 and 172013).

\section{References}

1 S. Rollas and Ş. G. Küçükgüzel, Molecules, 2007, 12, 19101939.

2 A. Kajal, S. Bala, N. Sharma, S. Kamboj and V. Saini, Int. J. Med. Chem., 2014, 2014, 1-11.

3 G. Verma, A. Marella, M. Shaquiquzzaman, M. Akhtar, M. R. Ali and M. M. Alam, J. Pharm. BioAllied Sci., 2014, 6, 69-80.

4 K. Padmini, P. J. Preethi, M. Divya, P. Rohini, M. Lohita, K. Swetha and P. Kaladar, Int. J. Pharma Res. Rev., 2013, 2, 43-58.

5 M. Asif and A. Husain, J. Appl. Chem., 2013, 2013, 1-7.

6 V. J. Negi, Int. J. Pharm. Chem., 2013, 2, 12-13.

7 R. d. C. Maia, R. Tesch and C. A. M. Fraga, Expert Opin. Ther. Pat., 2014, 24, 1161-1170.

8 K. C. Agrawal, B. A. Booth, R. L. Michaud, E. C. Moore and A. C. Sartorelli, Biochem. Pharmacol., 1974, 23, 2421-2429.

9 N. S. H. N. Moorthy, N. M. F. S. A. Cerqueira, M. J. Ramos and P. A. Fernandes, Mini-Rev. Med. Chem., 2013, 13, 18621872.

10 B. Fischer, K. Kryeziu, S. Kallus, P. Heffeter, W. Berger, C. R. Kowol and B. K. Keppler, RSC Adv., 2016, 6, 5584855859.

11 M. Liu, T. Lin and A. C. Sartorelli, Biochem. Pharmacol., 1994, 48, 335-344.

12 J. M. Shao, B. S. Zhou, a. J. Di Bilio, L. J. Zhu, T. L. Wang, C. Qi, J. Shih and Y. Yen, Mol. Cancer Ther., 2006, 5, 586592.

13 Y. Aye, M. J. C. Long and J. Stubbe, J. Biol. Chem., 2012, 287, 35768-35778.

14 A. Popović-Bijelić, C. R. Kowol, M. E. S. Lind, J. Luo, F. Himo, É. A. Enyedy, V. B. Arion and A. Gräslund, J. Inorg. Biochem., 2011, 105, 1422-1431.

15 K. Pelivan, W. Miklos, S. van Schoonhoven, G. Koellensperger, L. Gille, W. Berger, P. Heffeter, C. R. Kowol and B. K. Keppler, J. Inorg. Biochem., 2015, 160, 61-69.

16 C. R. Myers, Free Radical Biol. Med., 2016, 91, 81-92.

17 J. M. Myers, W. E. Antholine, J. Zielonka and C. R. Myers, Toxicol. Lett., 2011, 201, 130-136.

18 R. Trondl, L. S. Flocke, C. R. Kowol, P. Heffeter, U. Jungwirth, G. E. Mair, R. Steinborn, E. A. Enyedy, M. A. Jakupec, W. Berger and B. K. Keppler, Mol. Pharmacol., 2014, 85, 451-459.

19 S. Hill, S. Datta, J. Liu, R. Inglis, C. J. Milios, P. L. Feng, J. J. Henderson, E. del Barco, E. K. Brechin and D. N. Hendrickson, Dalton Trans., 2010, 39, 4693-4707.

20 H. Gang, G. Dong, D. Chun-Ying, M. Hong and M. Qing-jin, New J. Chem., 2002, 26, 1371-1377.

21 Y. Zhao, D. Guo, Y. Liu, C. He and C. Duan, Chem. Commun., 2008, 2, 5725-5727. 
22 L. Zhang, J. J. Wang and G. C. Xu, Inorg. Chem. Commun., 2014, 39, 66-69.

23 A. Bacchi, M. Carcelli, P. Pelagatti, C. Pelizzi and G. Pelizzi, J. Inorg. Biochem., 1999, 75, 123-133.

24 A. A. A. Abu-Hussen and A. A. A. Emara, J. Coord. Chem., 2004, 57, 973-987.

25 D. Y. Wu, O. Sato, Y. Einaga and C. Y. Duan, Angew. Chem., Int. Ed., 2009, 48, 1475-1478.

26 G. M. Abu El-Reash, O. A. El-Gammal and A. H. Radwan, Spectrochim. Acta, Part A, 2014, 121, 259-267.

27 J. R. Dimmock, S. N. Pandeya, J. W. Quail, U. Pugazhenthi, T. M. Allen, G. Y. Kao, J. Balzarini and E. DeClercq, Eur. J. Med. Chem., 1995, 30, 303-314.

28 F. A. French and E. J. Blanz, J. Med. Chem., 1966, 9, 585-589. 29 O. A. El-Gammal, G. M. Abu El-Reash, S. E. Ghazy and A. H. Radwan, J. Mol. Struct., 2012, 1020, 6-15.

30 S. Rhee, J. Pharm. Soc. Korea, 1972, 16, 162-175.

31 K. Gangarapu, S. Manda, S. Thota, R. Yerra, S. S. Karki, J. Balzarini, E. De Clercq and H. Tokuda, Lett. Drug Des. Discovery, 2012, 9, 934-941.

32 M. P. Sathisha, U. N. Shetti, V. K. Revankar and K. S. R. Pai, Eur. J. Med. Chem., 2008, 43, 2338-2346.

33 J. M. Pérez, V. Cerrillo, A. I. Matesanz, J. M. Millán, P. Navarro, C. Alonso and P. Souza, ChemBioChem, 2001, 2, 119-123.

34 V. R. Solomon and H. Lee, Curr. Med. Chem., 2011, 18, 14881508.

35 S. Adsule, V. Barve, D. Chen, F. Ahmed, Q. P. Dou, S. Padhye and F. H. Sarkar, J. Med. Chem., 2006, 49, 7242-7246.

36 Q. Ba, M. Hao, H. Huang, J. Hou, S. Ge, Z. Zhang, J. Yin, R. Chu, H. Jiang, F. Wang, K. Chen, H. Liu and H. Wang, Clin. Cancer Res., 2011, 17, 7625-7633.

37 M. Serda, D. S. Kalinowski, A. Mrozek-Wilczkiewicz, R. Musiol, A. Szurko, A. Ratuszna, N. Pantarat, Z. Kovacevic, A. M. Merlot, D. R. Richardson and J. Polanski, Bioorg. Med. Chem. Lett., 2012, 22, 5527-5531.

38 H. Huang, Q. Chen, X. Ku, L. Meng, L. Lin, X. Wang, C. Zhu, Y. Wang, Z. Chen, M. Li, H. Jiang, K. Chen, J. Ding and H. Liu, J. Med. Chem., 2010, 53, 3048-3064.

39 F. Bisceglie, A. Musiari, S. Pinelli, R. Alinovi, I. Menozzi, E. Polverini, P. Tarasconi, M. Tavone and G. Pelosi, J. Inorg. Biochem., 2015, 152, 10-19.

40 F. A. French, E. J. Blanz, S. C. Shaddix and R. W. Brockman, J. Med. Chem., 1974, 17, 172-181.

41 B. Beck and C. Blanpain, Nat. Rev. Cancer, 2013, 13, 727738.

42 M. S. Sosa, P. Bragado and J. A. Aguirre-Ghiso, Nat. Rev. Cancer, 2014, 14, 611-622.

43 R. P. Galvao, A. Kasina, R. S. McNeill, J. E. Harbin, O. Foreman, R. G. W. Verhaak, A. Nishiyama, C. R. Miller and H. Zong, Proc. Natl. Acad. Sci. U. S. A., 2014, 111, 4214-4223.

44 J. W. Uhr and K. Pantel, Proc. Natl. Acad. Sci. U. S. A., 2011, 108, 12396-12400.

45 M. Yang, H. Wang, Y. Hou, H. Tung, T. Chiu and Y. Shan, Mol. Cancer, 2015, 1-17.
46 P. Longati, X. Jia, J. Eimer, A. Wagman, M.-R. Witt, S. Rehnmark, C. Verbeke, R. Toftgård, M. Löhr and R. L. Heuchel, BMC Cancer, 2013, 13, 95-108.

47 E. Manoj, M. R. P. Kurup and E. Suresh, J. Chem. Crystallogr., 2008, 38, 157-161.

48 K. H. M. Ebrahim Tehrani, F. Kobarfard, P. Azerang, M. Mehravar, Z. Soleimani, G. Ghavami and S. Sardari, Iran. J. Pharm. Res., 2013, 12, 331-346.

49 C. A. Lipinski, F. Lombardo, B. W. Dominy and P. J. Feeney, Adv. Drug Delivery Rev., 2001, 46, 3-26.

50 R. L. Prior, X. Wu and K. Schaich, J. Agric. Food Chem., 2005, 53, 4290-4302.

51 M. T. Zimmerman, C. A. Bayse, R. R. Ramoutar and J. L. Brumaghim, J. Inorg. Biochem., 2015, 145, 30-40.

52 V. Calcatierra, Ó. López, J. G. Fernández-Bolaños, G. B. Plata and J. M. Padrón, Eur. J. Med. Chem., 2015, 94, 63-72.

53 B. Beck and C. Blanpain, Nat. Rev. Cancer, 2013, 13, 727738.

54 I. Murtaza, V. M. Adhami, B. Bin Hafeez, M. Saleem and H. Mukhtar, Int. J. Cancer, 2009, 125, 2465-2473.

55 B. Szomolay and V. Shahrezaei, BMC Syst. Biol., 2012, 6, 26.

56 E. J. Calabrese and M. P. Mattson, Journal of Cell Communication and Signaling, 2011, 5, 25-38.

57 A. R. Reynolds, Dose-Response, 2010, 8, 253-284.

58 E. Tsakalozou, A. M. Eckman and Y. Bae, Biochem. Res. Int., 2012, 2012, 1-10.

59 H. Hernández-Vargas, J. Palacios and G. Moreno-Bueno, Oncogene, 2007, 26, 2902-2913.

60 A. S. Reddy and S. Zhang, Expert Rev. Clin. Pharmacol., 2013, 6, 41-47.

61 D. R. McIlwain, T. Berger and T. W. Mak, Cold Spring Harbor Perspect. Biol., 2015, 7, a026716.

62 A. Jimbo, E. Fujita, Y. Kouroku, J. Ohnishi, N. Inohara, K. Kuida, K. Sakamaki, S. Yonehara and T. Momoi, Exp. Cell Res., 2003, 283, 156-166.

63 R. S. Hotchkiss and D. W. Nicholson, Nat. Rev. Immunol, 2006, 6, 813-822.

64 J. Alexandre, F. Batteux, C. Nicco, C. Chéreau, A. Laurent, L. Guillevin, B. Weill and F. Goldwasser, Int. J. Cancer, 2006, 119, 41-48.

65 D. Llobet, N. Eritja, M. Encinas, A. Sorolla, A. Yeramian, J. A. Schoenenberger, A. Llombart-Cussac, R. M. Marti, X. Matias-Guiu and X. Dolcet, Anti-Cancer Drugs, 2008, 19, 115-124.

66 I. Bairati, F. Meyer, M. Gelinas, A. Fortin, A. Nabid, F. Brochet, J.-P. Mercier, B. Tetu, F. Harel, B. Abdous, E. Vigneault, S. Vass, P. del Vecchio and J. Roy, J. Clin. Oncol., 2005, 23, 5805-5813.

67 G. Bjelakovic, D. Nikolova, L. L. Gluud, R. G. Simonetti and C. Gluud, JAMA, 2007, 297, 842-857.

68 D. Trachootham, Y. Zhou, H. Zhang, Y. Demizu, Z. Chen, H. Pelicano, P. J. Chiao, G. Achanta, R. B. Arlinghaus, J. Liu and P. Huang, Cancer Cell, 2006, 10, 241-252.

69 E. A. Bey, M. S. Bentle, K. E. Reinicke, Y. Dong, C.-R. Yang, L. Girard, J. D. Minna, W. G. Bornmann, J. Gao and D. A. Boothman, Proc. Natl. Acad. Sci. U. S. A., 2007, 104, 11832-11837. 
70 G. C. Brown and V. Borutaite, Mitochondrion, 2012, 12, 1-4.

71 J. Zielonka and B. Kalyanaraman, Free Radical Biol. Med., 2010, 48, 983-1001.

72 J. Kang and S. Pervaiz, Biochem. Res. Int., 2012, 2012, 1-14.

73 L. Papa, M. Hahn, E. L. Marsh, B. S. Evans and D. Germain, J. Biol. Chem., 2014, 289, 5412-5416.

74 A. E. Dikalova, A. T. Bikineyeva, K. Budzyn, R. R. Nazarewicz, L. McCann, W. Lewis, D. G. Harrison and S. I. Dikalov, Circ. Res., 2010, 107, 106-116.

75 Y. Zuo, B. Xiang, J. Yang, X. Sun, Y. Wang, H. Cang and J. Yi, Cell Res., 2009, 19, 449-457.

76 A. Jaggupilli and E. Elkord, Clin. Dev. Immunol., 2012, 2012, 1-11.

77 Y. Yan, X. Zuo and D. Wei, Stem Cells Transl. Med., 2015, 4, 1033-1043.

78 K. Williams, K. Motiani, P. V. Giridhar and S. Kasper, Exp. Biol. Med., 2013, 238, 324-338.

79 D. Naor, S. B. Wallach-Dayan, M. A. Zahalka and R. V. Sionov, Semin. Cancer Biol., 2008, 18, 260-267.

80 L. Li, X. Hao, J. Qin, W. Tang, F. He, A. Smith, M. Zhang, D. M. Simeone, X. T. Qiao, Z.-N. Chen, T. S. Lawrence and L. Xu, Gastroenterology, 2014, 146, 1108-1118.

81 F. Emhemmed, S. Ali Azouaou, F. Thuaud, V. Schini-Kerth, L. Désaubry, C. D. Muller and G. Fuhrmann, Biochem. Pharmacol., 2014, 89, 185-196.

82 D. R. Grimes, C. Kelly, K. Bloch and M. Partridge, J. R. Soc., Interface, 2014, 11, 20131124.

83 R.-Z. Lin and H.-Y. Chang, Biotechnol. J., 2008, 3, 1172-1184.

84 N. R. Filipović, S. Bjelogrlić, A. Marinković, T. Ž. Verbić, I. N. Cvijetić, M. Senćanski, M. Rodić, M. Vujčić, D. Sladić, Z. Striković, T. R. Todorović and C. D. Muller, RSC Adv., 2015, 5, 95191-95211.

85 L. Deschamps-Labat, F. Péhourcq, M. Jagou and B. Bannwarth, J. Pharm. Biomed. Anal., 1997, 16, 223-229.

86 K. W. Lexa, E. Dolghih and M. P. Jacobson, PLoS One, 2014, 9, e93323.
87 Principles of Fluorescence Spectroscopy, ed. J. R. Lakowicz, Springer Science Business Media, New York, USA, 3rd edn, 2006, p. 11.

88 J. Ghuman, P. A. Zunszain, I. Petitpas, A. A. Bhattacharya, M. Otagiri and S. Curry, J. Mol. Biol., 2005, 353, 38-52.

89 G. M. Morris, R. Huey, W. Lindstrom, M. F. Sanner, R. K. Belew, D. S. Goodsell and A. J. Olson, J. Comput. Chem., 2009, 30, 2785-2791.

90 P. C. D. Hawkins, A. G. Skillman, G. L. Warren, B. A. Ellingson and M. T. Stahl, J. Chem. Inf. Model., 2010, 50, 572-584.

91 P. D. Ross and S. Subramanian, Biochemistry, 1981, 20, 3096-3102.

92 T. A. Halgren, J. Comput. Chem., 1999, 20, 720-729.

93 J.-D. Chai and M. Head-Gordon, Phys. Chem. Chem. Phys., 2008, 10, 6615-6620.

94 J. Tomasi, B. Mennucci and R. Cammi, Chem. Rev., 2005, 105, 2999-3094.

95 K. Wolinski, J. F. Hinton and P. Pulay, J. Am. Chem. Soc., 1990, 112, 8251-8260.

96 P. Gaillard, P. A. Carrupt, B. Testa and A. Boudon, J. Comput.-Aided Mol. Des., 1994, 8, 83-96.

97 B. Ojha and G. Das, J. Phys. Chem. B, 2010, 114, 3979-3986. 98 Z. Wang, J. X. Ho, J. R. Ruble, J. Rose, F. Rüker, M. Ellenburg, R. Murphy, J. Click, E. Soistman, L. Wilkerson and D. C. Carter, Biochim. Biophys. Acta, Gen. Subj., 2013, 1830, 5356-5374.

99 D. Buttar, N. Colclough, S. Gerhardt, P. A. MacFaul, S. D. Phillips, A. Plowright, P. Whittamore, K. Tam, K. Maskos, S. Steinbacher and H. Steuber, Bioorg. Med. Chem., 2010, 18, 7486-7496.

100 J. J. P. Stewart, MOPAC2016, Stewart Computational Chemistry, Colorado Springs, CO, USA, 2016.

101 O. Trott and A. J. Olson, J. Comput. Chem., 2010, 31, 455-461.

102 A. Pedretti, L. Villa and G. Vistoli, J. Comput.-Aided Mol. Des., 2004, 18, 167-173. 